\title{
The Central Role of Acute Phase Proteins in Rheumatoid Arthritis: Involvement in Disease Autoimmunity, Inflammatory Responses, and the Heightened Risk of Cardiovascular Disease
}

\author{
Johannes A. Bezuidenhout, $\mathrm{MSc}^{1}$ Etheresia Pretorius, $\mathrm{PhD}^{10}$ \\ ${ }^{1}$ Department of Physiological Sciences, Stellenbosch University, \\ Stellenbosch, South Africa \\ Semin Thromb Hemost 2020;46:465-483.

\begin{abstract}
Address for correspondence Etheresia Pretorius, PhD, Department of Physiological Sciences, Faculty of Science, Stellenbosch University, Private Bag X1 Matieland, Stellenbosch 7602, South Africa (e-mail: resiap@sun.ac.za).
\end{abstract}

\begin{abstract}
Rheumatoid arthritis (RA) is an autoimmune disease of complex etiopathogenic origin and traditionally characterized by chronic synovitis and articular erosions. Furthermore, there is strong evidence that infectious agents, including those that become dormant within the host, play a major role in much of the etiology of RA and its hallmark of inflammation. A combination of genetic predisposition, environmental exposure, and presence of infectious agents may therefore lead to a loss of immune tolerance to citrullinated proteins, which present as self-antigens to the human immune system. This results in generation of highly RA-specific autoantibodies, known as anti-citrullinated protein antibodies (ACPAs). Protein citrullination occurs via posttranslational deamination of arginine residues by peptidylarginine deiminase enzymes, which have confirmed sources of both endogenous and infectious origins. A recognized plasma protein target of citrullination and RA autoantibody generation is fibrin and its soluble precursor fibrinogen, both key components of hemostasis and acute phase reaction. Increased titers of ACPAs that accompany rapid progression to clinical RA disease have been shown to drive a variety of proinflammatory processes, and therefore results in aberrant fibrin clot formation and increased cardiovascular risk.

Keywords

- rheumatoid arthritis

- hemostasis

- coagulation

- citrullination

- periodontitis However, the full extent to which hemostasis is affected in RA remains controversial, owing to the differential impact that citrullinated fibrin(ogen) and concurrent systemic inflammation may have on resulting hemostatic outcome. This review highlights key events in initiation of autoimmune-driven inflammatory events, including the role of bacterial infectious agents, which subsequently result in clinical RA disease and associated secondary cardiovascular disease risk, with specific focus on plasma proteins that are heavily involved throughout the immunopathological progression process.
\end{abstract}

Rheumatoid arthritis (RA) is the most common autoimmune disease, displaying a worldwide prevalence of 0.5 to $1 \%{ }^{1,2} \mathrm{RA}$ typically has a middle-aged onset that disproportionately affects females (threefold higher prevalence than males). ${ }^{3}$ Symptomatic RA is characterized by chronic systemic inflammation, resulting in bilateral and symmetrical polyarticular arthritis, persistent erosive synovitis, and development of autoantibodies. ${ }^{1,4}$ The clinical manifestations of chronic inflammation in RA are most commonly observed in the small joints of hands and feet. ${ }^{5}$ Common disease symptoms include pain, swelling of the joint, stiffness, and progressive destruction of joint structure. ${ }^{6}$ Irreversible damage to joint structure
Issue Theme Editorial Compilation VIII; Guest Editors: Emmanuel J. Favaloro, PhD, FFSc (RCPA), and Giuseppe Lippi, MD.
Copyright $\odot 2020$ by Thieme Medical Publishers, Inc., 333 Seventh Avenue, New York, NY 10001 , USA. Tel: +1(212) 760-0888.
DOI https://doi.org/ 10.1055/s-0040-1709475. ISSN 0094-6176.
License terms

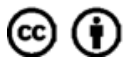


and subsequent loss of mobility can occur within 3 years of diagnosis in 20 to $30 \%$ of RA patients when appropriate treatment measures are not undertaken. ${ }^{7}$

RA is considered to be a prototypic polygenic disorder, as disease development is thought to occur as a result of the interaction between predisposing genetic risk factors and environmental exposures. ${ }^{8}$ The strongest genetic link associated with RA is the single nucleotide polymorphisms in the human leukocyte antigen (HLA)-DRß1 gene, which in some study cohorts have shown to be present in approximately 64 to $70 \%$ of RA patients and $55 \%$ of their first-degree relatives. ${ }^{9,10}$ HLA molecules belong to the major histocompatibility complex $(\mathrm{MHC})$ and is strongly linked to anti-citrullinated protein antibodies (ACPA) ${ }^{+}-$RA. $^{5}$ HLA-DRB1 genes exert major influence on the cluster of differentiation $4(\mathrm{CD} 4)^{+} \alpha \beta$ T cell repertoire, through their "shared epitope" (SE) alleles that present as self-peptides to $\mathrm{CD} 4^{+}$T-cells in the thymus. ${ }^{5,11}$

The most compelling current explanation for the development and perpetuation of clinical RA disease is the infection of certain mucosal sites (oral, intestinal, and pulmonary) where microbes, under the influence of environmental factors such as smoke and drugs along with genetic predisposition, trigger mucosal inflammation. ${ }^{12}$ Subsequent migration of mucosal macrophages and lymphocytes to articular spaces results in synovial inflammation and joint destruction. ${ }^{13}$ Research by Rashid and Ebringer has strongly linked the bacterium Proteus mirabilis to the development of $\mathrm{RA},{ }^{14}$ stemming from an increased incidence rate of urinary tract infections (UTIs) observed in affected individuals. ${ }^{15}$ P. mirabilis is a major causative agent of UTIs and is detected to a greater extent in RA patient urine, along with increased levels of antibodies directed toward the bacterium. ${ }^{16}$ The closely matched amino acid sequences of "E-S-R-R-A-L" contained in Proteus spp. hemolysins and "E-Q/KR-R-A-A" in the "SE" of RA-linked HLA-DR molecules result in the binding of cross-reactive anti-P. mirabilis antibodies to various "SE" containing immune cells, causing a plethora of proinflammatory responses related to clinical RA disease. ${ }^{17}$ The nature of the Proteus spp. relationship with RA possibly explains the disproportionate occurence of disease in middle-aged women, owing to inherent difference in the genitourinary tract resulting in higher frequencies of UTIs in females. ${ }^{18}$

Lipopolysaccharides (LPS) are major endotoxic components of gram-negative bacterial cell walls, and act as strong pathogen-associated molecular patterns (PAMPs) to stimulate various innate immune responses. ${ }^{19}$ High levels of LPS are present within the gut lumen as a result of numerous residing commensal bacteria, and LPS is normally unable to penetrate across healthy intestinal epithelium. ${ }^{20}$ However, LPS-mediated inflammation and breach of intestinal permeability occurs when homeostasis of the normal gut microbiome is disturbed. ${ }^{21}$ LPS is therefore able to enter blood circulation and contribute to various systemic inflammatory processes. The disruption of the normal gut microbiota, known as gut dysbiosis, is highly prominent in RA patients and could therefore contribute significantly to the chronic inflammatory state. ${ }^{22,23}$ LPS ligates with toll-like receptor (TLR-4) leading to the production of various proinflammatory cytokines (tumor necrosis factor $\alpha$ [TNF $\alpha$ ], interleukin- 6
[IL-6], interleukin-8 [IL-8], interleukin-12 [IL-12]) through the nuclear factor kappa $\mathrm{B}(\mathrm{NFK} \mathrm{B})$ signal transduction pathway. ${ }^{24}$ TLR-4 is expressed on various immune cells involved in RA inflammatory signaling.

The high levels of LPS associated with gut dysbiosis, which is common in RA patients, might also influence the hypercoagulable state seen in a high proportion of affected individuals. As discussed previously, LPS stimulate the release of proinflammatory cytokines via TLR-4 dependent pathways. This process has been shown to facilitate the increased expression of tissue factor (TF) by immune cells, thereby amplifying coagulation via the TF pathway. ${ }^{25,26}$ It has also been demonstrated that LPS, due to its highly lipophilic nature, is able to bind to fibrinogen and cause more acute fibrin polymerization. ${ }^{27}$

The general overview of the key immunopathogenic events in the clinical RA disease development is illustrated in - Fig. 1. We consider RA pathogenesis within a systems biology approach, providing evidence of bacterial infectious agents generating the autoimmune inflammatory response, while emphasizing the importance of hematological biomarkers of acute systemic inflammation (hypercoagulation and $\beta$-amyloid formation) in disease diagnosis and treatment. ${ }^{28}$

\section{Cardiovascular Complications in Rheumatoid Arthritis}

Together with the immunopathogenic profile in RA, there is evidence for increased cardiovascular disease (CVD) risk in these patients. ${ }^{29-31}$ Conventional risk factors (age, sex, obesity, hypertension, and hypercholesterolemia) do not fully account for premature development of CVD in RA, thus indicating a prominent role for chronic systemic inflammation in alterations of hemostatic and thrombotic function. ${ }^{32}$ Highly sensitive molecular markers of hemostatic function such as prothrombin factor $1+2\left(\mathrm{PF}_{1+2}\right)$, thrombin-antithrombin complex (TAT), D-dimer, thrombin-activatable fibrinolysis inhibitor (TAFI), TF, and fibrinogen are significantly elevated in RA patients compared with healthy individuals. ${ }^{33-35}$

Increased prevalence of an activated platelet profile has been observed in RA patients. ${ }^{36}$ Platelets have a dual role in affecting both inflammatory and hemostatic responses in RA. Activated platelets express P-selectin which binds soluble CD40 ligand (sCD40L), triggering the expression of inflammatory adhesion receptors, proinflammatory cytokines, and matrix metalloproteinases (MMPs). ${ }^{37}$ Increased levels of platelet activity markers (sCD40L, P-selectin) are associated with RA disease activity. ${ }^{36}$ In addition to stimulation of platelets by TNF $\alpha$, ACPAs are also capable of directly influencing platelet activity through Fcr-RIIa-dependent binding. ${ }^{36}$ Some proteins released from platelet granules are associated with formation of more compact fibrin clot structures (e.g., increasing concentrations of platelet factor 4 and factor XIII which have fibrin cross-linking properties). ${ }^{38,39}$

TF is a transmembrane glycoprotein that functions as a cellular receptor and an important initiator of coagulation. ${ }^{40}$ TF expression is upregulated in the RA synovium and present on key proinflammatory mediators such as fibroblast-like synoviocytes, B-cells, and macrophages. ${ }^{41}$ Proinflammatory 


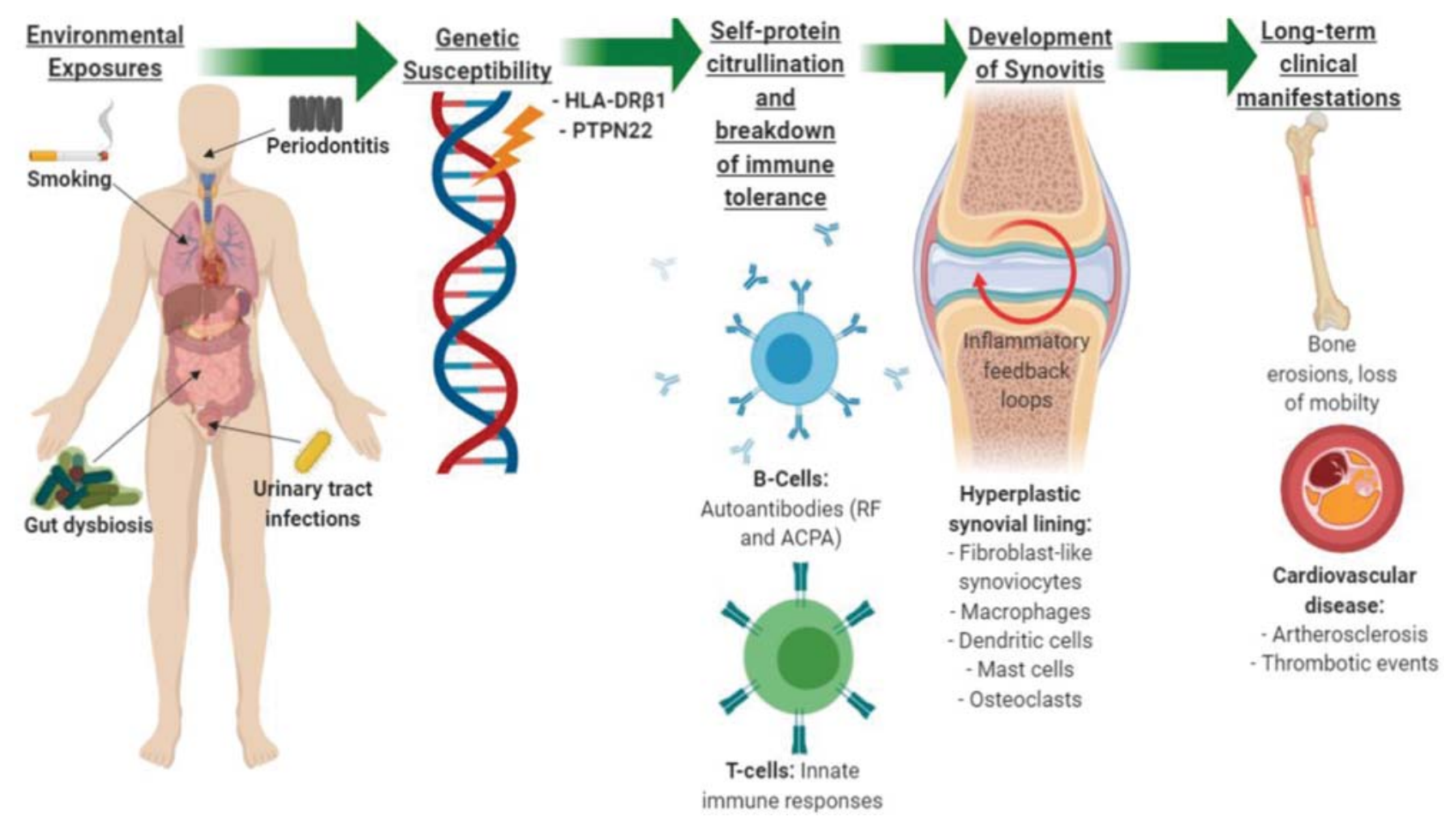

Fig. 1 The outline of key events in the immunopathogenesis of rheumatoid arthritis (RA). (Original figure; created with Biorender.com).

cytokines (TNFo, IL-1) facilitate thrombus formation by stimulating the procoagulant activity of endothelial cells, leading to increased TF expression. ${ }^{42}$

Fibrin fiber generation and structure are abnormally altered in RA as a result of the underlying inflammatory processes. ${ }^{43}$ Aberrant fibrin deposition in RA plasma as seen by scanning electron microscopy (SEM) is illustrated in - Fig. 2. The increased levels of fibrin deposition contribute the structural integrity of pannus in RA synovia. ${ }^{44}$ Pannus refers to the abnormal proliferation of synovial tissue lining, composed of stimulated fibroblasts, immune cells, and enriched vasculature. ${ }^{45}$ The presence of pannus formation in the synovium contributes to perpetual stimulation of local inflammation and erosion of extra-articular cartilage and bone. ${ }^{45}$

Levels of hemostasis factors responsible for thrombus generation (fibrinogen, von Willebrand factor, plasminogenactivator inhibitor I) are increased in RA patients. ${ }^{31,35}$ Characteristics of fibrin clot structure in RA include thick, matted layers of fibrin fibers with increased diameter. ${ }^{43}$ Unusual projections in RA patient fibrin fibers are also present owing to interactions with various proinflammatory mediators. ${ }^{34}$ These ultrastructural alterations result in fibrin clots that are significantly less stable, permeable, and lysable compared with clots formed under physiological conditions. ${ }^{34}$

Increased levels of fibrinolysis biomarkers (i.e., D-dimer, $\mathrm{PF}_{1+2}, \mathrm{TAT}$ ) have been associated with RA disease activity and inflammation. ${ }^{33,35}$ However, inflammation also induced TAFI, which favors fibrin persistence and prevents the protein breakdown. ${ }^{35}$ Previously described ultrastructural alterations also contribute to decreased breakdown of fibrin clots. ${ }^{34,43}$ Citrullinated-fibrinogen immune complexes impair the activity of plasmin, leading to decreased levels of fibrinolysis and sustained synovial damage through proinflammatory effec- tors. ${ }^{46}$ These findings further support the notion of an impaired hemostatic balance of fibrin clot formation and breakdown in RA patients. CVD risk, inflammation, hypercoagulation, and immunopathology may be closely interlinked in RA pathology. The main immunological hallmarks and diagnostic biomarkers of RA are known to be rheumatoid factor (RF) and ACPAs. The development of autoimmunity in RA may be driven by a bacterial presence that may play important roles in the development of hypercoagulation in RA.

\section{Diagnostic Markers in Rheumatoid Arthritis with Specific Focus on Anti-Citrullinated Protein Antibodies}

The presence of two notable autoantibodies in RA patient sera, namely RF and ACPA, is a hallmark characteristic of the disease. RFs were the first identified autoantibodies to be linked with RA and target the Fc portion of immunoglobulin $G(\operatorname{IgG}){ }^{47}$ RF has very low specificity for RA, as it is detected in other rheumatic disorders and in healthy individuals, ${ }^{48,49}$ whereas there is strong evidence for the role of ACPAs in RA immunopathogenesis. ${ }^{50}$ However, the presence of both IgA-RF and ACPA in the preclinical phase is predictive of more rapid disease onset, with increased severity and decreased possibility of remission..$^{51}$ The concomitant effect of RF and ACPAs in RA patients stimulates in vivo proinflammatory cytokine production, which increases the risk of significant bone mineral density loss. ${ }^{52}$ Recently, the cross-reactivity of RF with citrullinated fibrinogen, which is distinct from its primary IgG1-Fc target, has been reported. ${ }^{53}$ This occurs as a result of sequence homology between the Fc and citrullinated fibrinogen epitopes, both of which contain arginine residues. ${ }^{53}$ These findings could therefore mechanistically explain the 


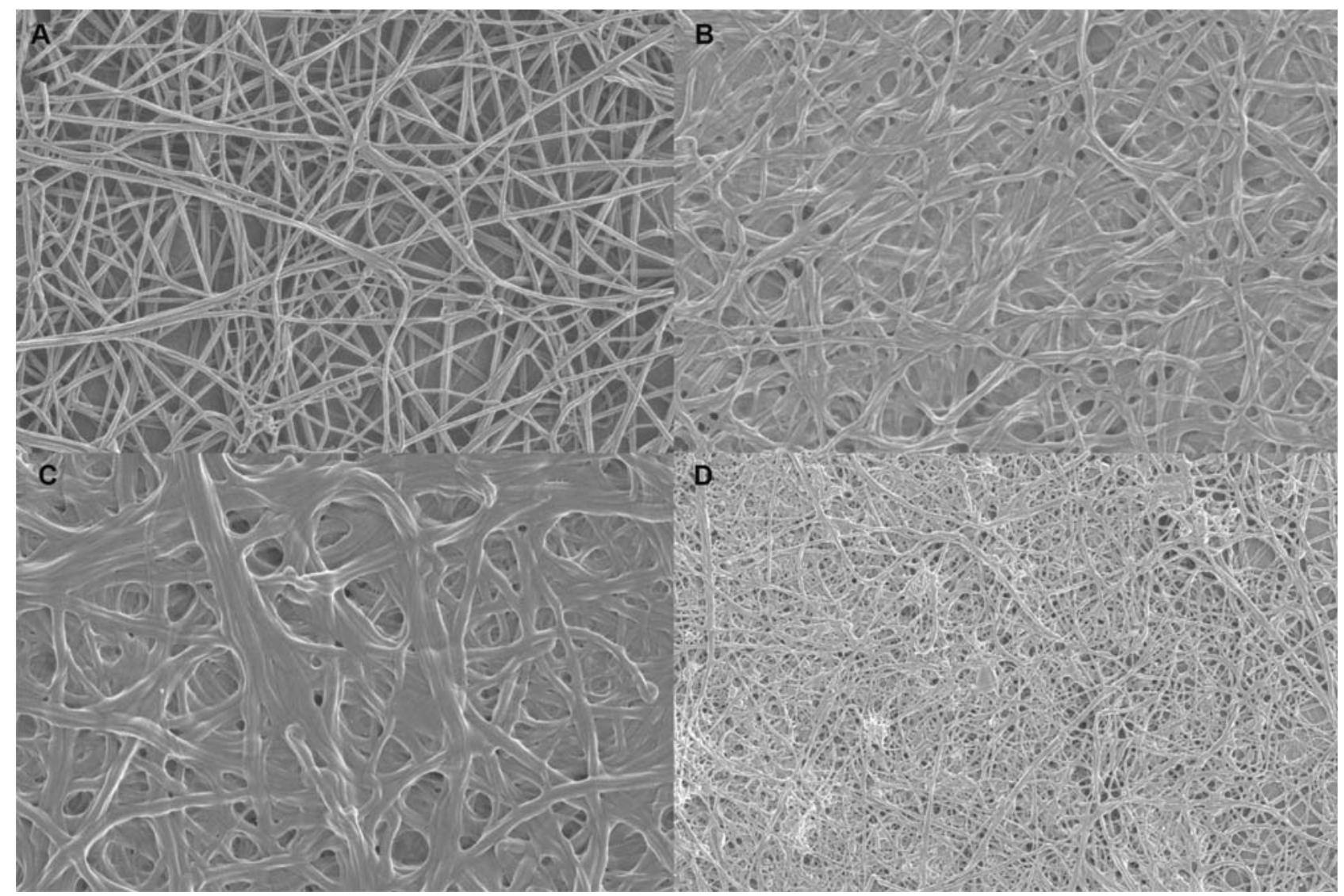

Fig. 2 A series of scanning electron microscopy images illustrating the difference in fibrin clot structure of a healthy control (A) and RA patients (B-D). (Unpublished work by authors).

occurrence of more severe disease severity in RA patients with positive sera for both RFs and ACPAs.

Citrullination is a physiologically occurring process during apoptosis, inflammation, or epithelial keratinization. ${ }^{54}$ The amino-acid arginine is posttranslationally modified by peptidylarginine deaminase (PAD) enzymes to form citrulline, a nonstandard amino acid. ${ }^{54}$ Modification of proteins in this manner results in an increase of molecular mass $(1 \mathrm{kDa}$ compared with regular arginine residues $)^{55}$ and a reduction of the net positive charge, causing the loss of potential ionic bonds and interference of hydrogen bonds. ${ }^{56}$ These conformational changes ultimately result in unfolding of protein structure. ${ }^{56}$ Various protein targets for citrullination exist, including human fibrin(ogen), ${ }^{57}$ histones, ${ }^{58}$ vimentin, ${ }^{59}$ $\alpha$-enolase, ${ }^{60}$ and types I- and II collagen. ${ }^{61,62}$ Citrullination enhances peptide affinity toward MHC molecules, leading to activation of $\mathrm{CD}^{+}{ }^{+}$T-cells. ${ }^{63}$ ACPAs are then produced in response to the presence of citrullinated peptides or proteins. ${ }^{54,64}$ ACPAs are highly specific to $\mathrm{RA}^{65}$ present prior to clinical disease onset, ${ }^{66}$ and are indicative of more severe disease activity and rapid structural damage. ${ }^{67}$

\section{Generation of Citrullinated Autoantigens}

PADs are intracellular, $\mathrm{Ca}^{2+}$-dependent deaminase enzymes that are usually inactive under normal physiological conditions. ${ }^{68}$ PAD enzymes become activated during large-scale apoptotic or inflammatory events as a result of plasma or organelle membrane disintegration, causing extracellular $\mathrm{Ca}^{2+}$ influx or PAD enzyme liberation from cellular compartments. ${ }^{69-71}$ The abnormal humoral response to the presence of citrullinated proteins results from insufficient phagocytic clearance of apoptotic remnants under severe inflammatory conditions. $^{70-72}$ Five mammalian isoforms of PAD are known (PAD1, PAD2, PAD3, PAD4-5, PAD6), of which PAD2 and PAD4 are primarily responsible for the generation of autoantibodies in RA. ${ }^{4,73}$ PAD2 and PAD4 are expressed by several peripheral blood leukocytes present in the RA synovium, in addition to performing regulatory functions related to gene expression, central nervous system development, and tumorigenesis. ${ }^{4,71,73,74}$ PAD2 and PAD4 exhibit different subcellular localization and antigen target specificities in RA and are associated with the presence of inflammatory markers. ${ }^{75,76}$ The most prominent protein targets for PAD-driven citrullination are human fibrin(ogen), ${ }^{57}$ histones, ${ }^{58}$ vimentin, ${ }^{59} \alpha$-enolase, ${ }^{60}$ and types I- and II collagen. ${ }^{61,62}$

The primary environmental risk factors associated with RA development are infection ${ }^{76}$ and smoking. ${ }^{77}$ There has also been strong emerging evidence of the role of infectious agents in the initiation and progression of rheumatic diseases. The prevalence of periodontitis in RA patients (35\% in all patients and $37 \%$ in $\mathrm{ACPA}^{+}$-RA patients) is significantly increased compared with individuals not diagnosed with RA. ${ }^{78}$ Periodontitis has been associated with various RA disease markers, such as disease activity scores (DAS-28), C-reactive protein 
(CRP), erythrocyte sedimentation rate, and anticyclic citrullinated peptide (CCP) antibodies. ${ }^{78-80}$ Okada et al also demonstrated that clinical disease presentation is improved with periodontal treatment in RA patients. ${ }^{81}$ Emerging evidence suggests that RA may develop at extra-articular mucosal sites (lungs and oral cavities), where exposure of HLA-DR $\beta 1$ risk genes to environmental sources of inflammation (tobacco smoke and bacterial or viral infection) is most likely to occur. ${ }^{76}$ This results in the generation of an aggressive autoimmune response and subsequent assault of self-tissues. ${ }^{76}$

\section{Anti-Citrullinated Autoantibodies}

Synovial fluid-derived B cells are responsible for generating ACPAs in RA. ${ }^{82}$ Varying degrees of ACPA cross-reactivity have been demonstrated, ranging from monoreactive antibodies to reactivity with multiple citrullinated antigens. ${ }^{83,84} \mathrm{Li}$ et al indicated that $66.7 \%$ of plasmablast-derived ACPAs from RA patients demonstrated cross-reactivity with different citrullinated epitopes, while $33 \%$ of the patients had monoreactive ACPA subsets that recognize either citrullinated fibrinogen, citrullinated enolase, or citrullinated vimentin. ${ }^{85}$ The mode in which ACPAs target citrulline-containing peptide antigens is dependent on appropriate molecular motifs, specifically sequences in which citrulline residues are flanked by other small and neutral amino acids. ${ }^{86}$

In the preclinical stage of RA development, increased ACPA titers are accompanied by increased levels of epitope spreading to recognize a broader range of citrullinated antigens. ${ }^{87,88}$ However, no further expansion of epitope recognition is observed after disease onset. ${ }^{89}$ The presence and level of antigen recognition by ACPAs in the RA synovium determine the magnitude of the immune response. ${ }^{90}$ The magnitude of the patient ACPA isotype profile is also strongly predictive of long-term radiographic progression. ${ }^{91}$

The presence of ACPAs represent a specified subgroup that constitutes 70 to $80 \%$ of all RA patients. ${ }^{74,75}$ These observations indicate a strong role of ACPAs in development of clinical RA, ACPAs are therefore listed as an important criterion for RA disease classification in American College of Rheumatology/ European League against Rheumatism (ACR-EULAR) guidelines. $^{92}$ The discovery of the first citrullinated antigens (filaggrin) and ACPAs (antikeratin factor and antiperinuclear factor) in $\mathrm{RA}^{93,94}$ led to the development of enzyme-linked immunosorbent assay (ELISA)-based methods for detecting ACPAs. ${ }^{95}$ Known as anti-CCP tests, these detection methods are considered the gold standard for detection of ACPA presence in RA patients. First generation anti-CCP tests displayed 68\% sensitivity and 97 to $98 \%$ specificity for RA diagnosis, ${ }^{95}$ with improved results in second generation anti-CCP2 tests $(80 \%$ sensitivity and $98 \%$ specificity). ${ }^{96}$ However, anti-CCP detection captures overlapping ACPA cross-reactivity and therefore cannot determine single ACPA-subtype specificity. ${ }^{83}$

\section{Fibrinogen in Rheumatoid Arthritis}

Fibrinogen is a large ( $340 \mathrm{kDa}$ ) glycoprotein that is synthesized in the liver and circulates in blood at concentrations between 2 and $4 \mathrm{~g} / \mathrm{L} .{ }^{97}$ The triglobular structure consists of paired $\alpha-, \beta-$, and $\gamma$-polypeptide chains linked by disulfide bonds via their $N$ - terminal regions. ${ }^{97-99}$ Fibrinogen is the soluble precursor of insoluble fibrin, the terminal component of the common coagulation pathway with thrombin responsible for the proteolysis of fibrinogen. ${ }^{98,100}$ Thrombin, a trypsin-like serine protease, cleaves fibrinogen between Arg-16 and Gly-17 of the $A \alpha$ chain and Arg-14 and Gly-14 of the B $\beta$ chain to expose polymerization sites, resulting in release of fibrinopeptide $A$ and fibrinopeptide from their respective $\mathrm{N}$-terminal regions. ${ }^{97,98}$ Fibrin monomers polymerize spontaneously, mediated by activated factor XIII (FXIIIa) that cross-link individual fibrin molecules to form a complex, stable, and insoluble branching network of fibrin fibers. ${ }^{97}$ In the event of vascular injury, fibrinogen is digested by thrombin, and generates clots consisting of dense fibrin fiber networks. ${ }^{43,98}$ During systemic inflammatory states, characteristic of clinical RA, excessive fibrinogen generation and degradation occur. ${ }^{101}$

The role that fibrinogen and fibrin (in both native and citrullinated forms) play in RA disease development and progression will be extensively discussed further in this review, with specific focus on cardiovascular disease as a secondary risk in RA patients. Fibrinogen fulfils a unique role in rheumatic disease as it not only is involved in the conventional interplay between chronic local and systemic inflammation with dysregulated coagulation, but also actively contributes to the development of the autoimmune response. Insights into the role that fibrinogen/fibrin plays at each level of disease progression may provide the necessary knowledge to identify novel therapeutic targets and treatment strategies to alleviate severe disease symptoms.

As mentioned previously, there is a strong genetic link associated with RA, where the HLA-DR $\beta 1$ gene is the most well-known implicated gene. ${ }^{9,10}$ The extent to which citrullinated fibrinogen peptides may influence HLA-DR $\beta 1$-mediated immune responses in RA remains unclear. Several studies observed no significant T-cell response or arthritogenic induction to citrullinated-fibrinogen immunization of HLA-DR $\beta 1$ transgenic mice. ${ }^{100,102,103}$ However, the presence of antibodies to citrullinated fibrinogen (ACF) is associated with human HLA-DRß1-0404* allele along with early disease onset and radiographic progression. ${ }^{104}$ The arthritogenic potential of citrullinated-fibrinogen in HLA-DR4 transgenic mice has also been reported by Raijmakers et al. ${ }^{55}$ Possible reasons for these discrepancies include increased ACPA heterogeneity in human RA, increased number of sites available for citrullination on human fibrinogen, and differences between the T-cell repertoire of humans and murine models. ${ }^{103}$ The humoral response in murine models is also dependent on the strain, immunogen, and the immunization protocol used. ${ }^{102}$ Citrullinated fibrinogen has also been associated with the presence of protein tyrosine phosphatase, non-receptor type 22 (PTPN22) R620W risk alleles. ${ }^{100}$ PTPN22 promotes the survival of B-cells in RA and other inflammatory conditions, such as type 2 diabetes, by evading tolerance checkpoints. ${ }^{105-107}$

\section{Fibrinogen and Fibrin Are Endogenous Sources of RA Autoantigens}

As described previously, fibrin and fibrinogen are major targets for PAD citrullination and could therefore play a role 
in the immunopathogenesis of RA. ${ }^{55,57,108}$ RA is characterized by excessive generation and breakdown of fibrinogen, in addition to deposition of fibrin within the inflamed RA synovium, even in cases of well-controlled disease. ${ }^{109,110}$ Increased plasma fibrinogen levels in RA have been reported to positively associate with disease activity scores and acute-phase markers such as CRP and serum amyloid A (SAA). ${ }^{110}$ The presence of immune complexes containing citrullinated fibrin(ogen) and autoantibodies directed toward the citrullinated forms of fibrin(ogen) has been confirmed in human RA sera and synovial fluid in various studies. ${ }^{55,57,100,101,108}$ The presence of circulating immune complexes containing citrullinated fibrinogen has been reported in half of anti-CCP ${ }^{+} \mathrm{RA}$ patients in a study by Zhao et al. ${ }^{111}$ ACF antibodies have predominantly nonoverlapping reactivity, and target citrullinated fibrinogen peptides more favorably than native fibrinogen. ${ }^{100}$ ACF-ELIZA detection tests display similar performance to commercial anti-CCP2 assays and are highly predictive of rapid radiographic progression in terms of RA specificity. ${ }^{112,113}$ The detection of both citrullinated fibrinogen antigens and autoantibodies directed toward such peptides, along with reported findings of arthritis development in certain murine models when immunized with both native and citrullinated forms of fibrinogen, ${ }^{102,114}$ strongly suggests a pathogenic role for fibrinogen and fibrin in human RA.

Deamination of arginine residues to citrulline leads to an increase in nominal molecular mass of $1 \mathrm{kDa}$ per altered amino acid residue. ${ }^{55}$ This leads to an overall molecular mass increase of $31 \mathrm{kDa}$ in the $A \alpha$ fibrinogen subunit and $21 \mathrm{kDa}$ in the $\mathrm{B} \beta$ fibrinogen subunit, respectively. ${ }^{97}$ Two-thirds of arginine residues in fibrinogen are susceptible to citrullination by both PAD2 and PAD4 isoforms, with the most prominent citrullination sites located on the $A \alpha$ (highest amount of target sites) and $B \beta$ fibrinogen subunits. ${ }^{46,97,115}$ Fibrinogen $\gamma$-chains and fibrinogen-derived degradation products are not significantly targeted for citrullination by PAD enzymes. ${ }^{97}$ PAD2 and PAD4 enzymes recognize different epitopes for citrullination in fibrinogen and fibrin peptide chains. ${ }^{116}$ Studies have demonstrated that PAD2 is more efficient in deamination of arginine residues in fibrinogen and fibrin chains ${ }^{75}$ and induces a significantly higher proinflammatory response ${ }^{117}$ than PAD4. The enhanced efficiency of PAD2 for deaminating arginine residues is due to the enzyme being less restricted by the amino acid composition surrounding acceptor arginine residues in fibrinogen and fibrin compared with PAD4. ${ }^{75}$ There is no significant discrimination of ACF-directed reactivity toward citrullinated peptides generated by either PAD2 or PAD4, as there is a great degree of overlap in the citrullination sites targeted by both PAD2 and PAD4. ${ }^{75}$ The mapping of citrullinated epitopes in fibrinogen and fibrin has been conducted by a large number of studies. The identification of 42 citrullinated residues in fibrinogen ( 27 in the $\alpha$-chain, 11 in the $\beta$-chain and 4 in the $\gamma$-chain) currently represents the most comprehensive epitope list for citrullinated fibrinogen compiled thus far. ${ }^{115}$ Fibrin contains a decreased amount of susceptible arginine residues for citrullination compared with soluble fibrinogen. ${ }^{4,46}$ The major citrullination epitopes contained in fibrin have been reported as $A \alpha_{36-50}$ and $B \beta_{60-74}$, respectively. ${ }^{46,57}$
Despite evidence of significantly increased levels of fibrin clot formation and fibrinolysis in various studies, limited research regarding the proteolysis of citrullinated fibrinogen peptides has been conducted. Paradoxical observations regarding the involvement of citrullinated fibrinogen in the thrombin-catalyzed fibrin polymerization reaction have been made in some literature. Studies by Nakayama-Hamada et al and Okumura et al found that citrullinated fibrinogen peptides are resistant to thrombin digestion under reverse phase high-performance liquid chromatography (HPLC) conditions. ${ }^{97,98}$ The inhibition of thrombin-catalyzed fibrinogen polymerization most likely occurs due to the citrullination of arginine residues within the thrombin cleavage sites in A $\alpha$ and $\mathrm{B} \beta$ fibrinogen chains, preventing thrombin binding. ${ }^{97,98,118}$ SEM analysis by Okumura et al of fibrin clot structure comparing samples containing native fibrinogen and native fibrinogen with citrullinated fibrinogen in combination indicated no significant difference in terms of fibrin fiber density and diameter between samples. ${ }^{97}$ These findings confirm that citrullinated-fibrinogen does not participate in thrombin-catalyzed fibrin clot formation. Citrullinated fibrinogen could therefore be regarded as an uncompetitive inhibitor of the thrombin reaction in the coagulation process. ${ }^{98}$ This impairment may suggest an effect of citrullination on the hemostatic balance in RA patients, but this directly conflicts with multiple observations of excessive fibrinogenesis and fibrinolysis in previous studies. Possibly explaining this phenomenon is that excessive levels of thrombin in RA synovial fluid increase the likelihood that high amount of fibrinogen is polymerized within the inflamed synovium, despite the concurrent presence of deaminating enzymes. ${ }^{35,119}$ The reduced fibrinolytic ability of plasmin has also been observed following fibrin citrullination. ${ }^{120}$ Plasmin is a serine proteinase that cleaves peptide bonds near basic amino acid residues such as arginine, and therefore deamination will reduce the amount of potential degradation sites. ${ }^{120}$

\section{Possible Interaction between Protein Deamination and Amyloidogenic Clot Formation}

As discussed earlier in this review, the deamination of arginine residues in plasma proteins such as fibrinogen is observable in RA patient sera and brings about a change in structural conformation. Arginine residues contribute to tertiary protein structure by forming noncovalent intramolecular bonds with acidic residues. ${ }^{121}$ Citrulline lacks the polarity of arginine, and the conversion of arginine to citrulline by PADs will therefore disrupt key structural features within protein molecules (-Fig. 3). ${ }^{121}$ It has been reported that 54 of the 81 arginine residues (66\%) within human fibrinogen are susceptible to deamination by either PAD2 or PAD4, ${ }^{115}$ indicating that substantial protein structural modification could take place. The normal function of fibrinogen would inevitably also be altered, as discussed previously in the form of autoantibody-driven inflammatory responses and disrupted fibrin polymerization and degradation. The major sites of the fibrinogen molecule affected by citrullination are the paired $A \alpha, B \beta$, and $\gamma$ peptide chains within the $D$-regions that flank the central nodule of the 


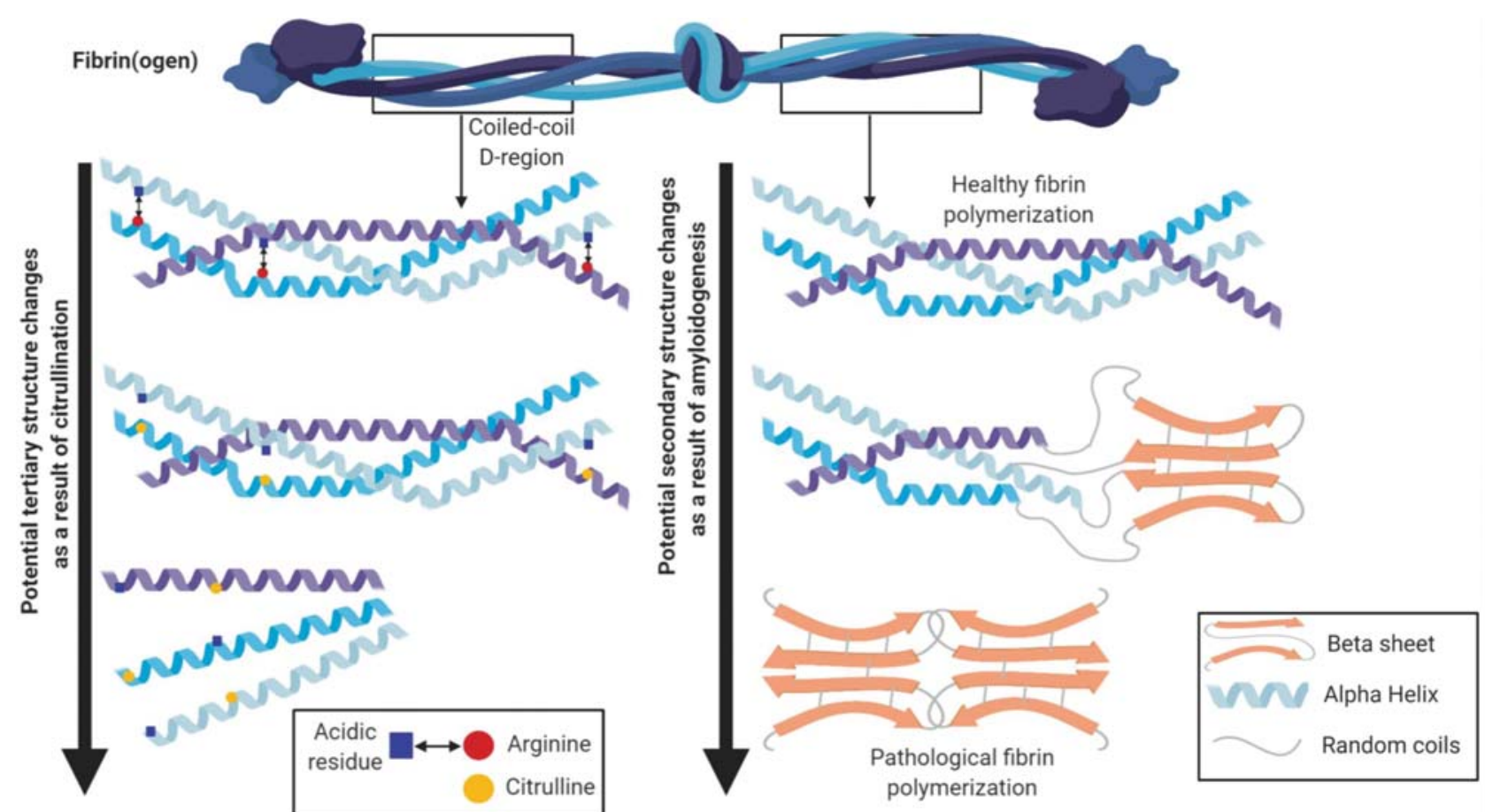

Fig. 3 Comparison of protein structure modification during citrullination and amyloidogenesis. Deamination of polar arginine residues interferes with intramolecular bonds, causing potential unfolding of tertiary protein structure. Under increasing mechanical force or pathological stress, $\alpha$-helices transition to $\beta$-sheets in fibrin, resulting in a pathologically altered clot. (Original figure; created using Biorender.com).

fibrinogen molecule. ${ }^{115}$ Paired structures within the fibrinogen molecule are held in place by 29 disulfide bridges formed between cysteine amino acid residues. ${ }^{122}$ These individual peptide chains consist of an $\alpha$-helical secondary protein structure, that wind around each other to form an $\alpha$-helical coiled-coil structure. ${ }^{123}$ The $\alpha$-helical coiled-coil conformation comprises approximately $25 \%$ of the amino acid architecture of the entire fibrinogen molecule. ${ }^{124}$ The normal elastic and plastic properties of fibrin(ogen) are highly dependent on the ability of coiled-coils to unwind, and the conversion of $\alpha$ helical coiled-coils to a $\beta$-sheet formation under mechanical stress has been demonstrated. ${ }^{125,126}$ Staining of these $\beta$-sheet structures in mechanically altered fibrin(ogen) by Congo-red revealed that these structures closely resemble the $\beta$-sheet aggregation seen in amyloid proteins. ${ }^{127}$

The relevant biophysical definition of amyloid is described as "unbranched protein fibers whose repeating substructure consists of $\beta$ strands that run perpendicular to the fiber axis, forming a cross $\beta$-sheet of undefined length." 128 Amyloid proteins have been traditionally linked with conditions such as Alzheimer's disease (deposition of amyloid- $\beta$ in senile plaques) and type 2 diabetes (islet amyloid polypeptide). ${ }^{129}$ Amyloidosis are a category of protein-misfolding disorders in which soluble proteins undergo conformational changes and are deposited in extracellular locations as aberrant, insoluble fibrillar structures that disrupt tissue structure and function. ${ }^{130}$ Fibrinogen is not generally considered amyloidogenic, except in rare cases of mutations in the fibrinogen $A \alpha$ genes, which seem to be the most common cause of hereditary renal amyloidosis. ${ }^{131}$ However, our group has demonstrated anomalous fibrin clot formation that is amyloid in nature in several inflammatory diseases. ${ }^{132-134}$ The same aberrant clot formation has also been demonstrated in a purified fibrinogen model in the presence of certain inflammatory stimuli such as bacterial LPS $^{27,135}$ and SAA. ${ }^{136}$

It therefore begs the question whether any interaction may occur between the processes of citrullination and amyloid transformation of fibrin(ogen) as outlined in - Fig. $\mathbf{3}$, and if it could play a major role in disease outcome in RA. This notion is substantiated by the occurrence of abnormal clot formation and presence of bacterial LPS from a dormant blood microbiome (seen as causal agents of amyloid fibrin formation) that seems intrinsically related to RA as well. However, limited research has been conducted with regards to the direct impact these two protein modification processes have upon each other. Osaki and Hiramatsu conducted research on the effect of citrullination on the single arginine residue conserved in the two isotypes of amyloid $\beta$ protein $\left(A \beta_{1-40}\right.$ and $\left.A \beta_{1-42}\right){ }^{137} A \beta$ is the major component of insoluble amyloid plaques in Alzheimer's disease (AD) neural tissue, with the 42-peptide isoform considered the most neurotoxic. The soluble, prefibrillar amyloid- $\beta$ oligomers are also implicated in causing significant neurotoxicity and cytotoxicity in AD. ${ }^{138}$ Citrullination of $A \beta_{1-40}$ resulted in an increased fraction of soluble amyloid oligomers, and citrullination of $A \beta_{1-42}$ caused in an increased fraction of $\beta$-sheet rich oligomers. ${ }^{137}$ These findings suggest that citrullination causes structural changes bearing implication for the aggregative nature of amyloid proteins and providing some compelling additional research questions. Could citrullination of fibrin(ogen) $\alpha$-helical coiled-coil regions that result in tertiary structural changes create favorable conditions for conversion to pathogenic, amyloid-like 
$\beta$-sheet structures by LPS and SAA molecules? Conversely, could fibrin clots that become amyloid in nature provide suitable epitopes for PAD enzymes, thus resulting in enhanced autoantibody driven inflammatory responses? Further investigation to assess the extent that the processes of citrullination and amyloidogenesis affect each other could further enhance current knowledge on the nature of aberrant fibrin clot formation seen in RA.

\section{Acute Phase Reaction}

The acute phase response is highly prominent in RA as both a result and a contributor to the chronic inflammatory state in affected individuals. Acute SAA (A-SAA) is of particular significance, as it is a highly sensitive marker of acute inflammation (increases 1,000-fold above normal) and is therefore highly elevated in RA patients, even within individuals that present with improved clinical symptoms. ${ }^{139-142}$ A-SAA is the circulating precursor of amyloid A protein, a fibrillar, insoluble apolipoprotein that is deposited in major organs (amyloidosis) leading to the severe risk of organ damage and possible death. ${ }^{143-145}$ Despite being primarily produced by the liver, extrahepatic sources of SAA have also been identified. ${ }^{146} \mathrm{~A}$ SAA is expressed by synovial fibroblasts, ${ }^{146,147}$ monocytes/ macrophages, ${ }^{146,148}$ and endothelial cells. ${ }^{146}$ A-SAA synthesis is also stimulated by various proinflammatory cytokines such as IL-6, IL-1, TNF- $\alpha$, and IFN- $\gamma{ }^{142}$ A-SAA is also able to induce several proinflammatory processes contributing to RA immunopathogenesis. A-SAA promotes the expression of vascular cell adhesion molecule 1 (VCAM-1) and intercellular adhesion molecule-1 (ICAM-1) and the adhesion of peripheral blood mononuclear cells to synovial fibroblasts and thus accelerating pannus formation. ${ }^{149}$ A-SAA also mediates the production of MMPs by synovial fibroblasts, thus contributing to joint destruction. $^{149}$

Recently our group has demonstrated the ability of SAA to bind to fibrin(ogen), and that relatively low concentrations of SAA-induced amyloid fibrillation of fibrin clots. ${ }^{136}$ Amyloidogenic formation of proteins occurs when $\alpha$-helices uncoil resulting in $\beta$-sheet structure ${ }^{125}$ with misfolded proteins leading to an increased thrombotic tendency. ${ }^{150}$ With previous reported findings of significantly elevated levels of ASAA in RA patients, including patients with improved clinical symptoms, A-SAA may significantly contribute to coagulopathy seen in RA individuals and should thus be closely monitored in clinical settings. LPS-mediated $\beta$-amyloid formation of fibrin networks through the ability of LPS to bind human fibrin(ogen) has also been demonstrated. ${ }^{27}$

\section{Involvement of Bacterial Components in Immunopathogenesis and Hemostatic Complications of Rheumatoid Arthritis}

\section{Porphyromonas gingivalis as Environmental Source of (Fibrinogen) Citrullination}

As mentioned in the introduction, gingivitis and periodontitis are now increasingly implicated in development and progression of RA. Porphyromonas gingivalis, the major etiological cause of periodontitis, has received significant attention as a possible risk exposure for RA development. $P$. gingivalis is a gram-negative, asaccharolytic, and highly proteolytic bacterium, ${ }^{151,152}$ and is the only known prokaryote to produce deaminating enzymes similar to that of human isoforms, termed $P$. gingivalis peptidylarginine deaminase (PPAD). ${ }^{152}$ Human PAD enzymes, particularly PAD2 and PAD4, are the major sources of citrullinated antigens that drive the development of RA autoimmunity. It is therefore suggested that an external source of citrullination through bacterial PPAD activity could significantly contribute to the generation of RA-specific autoantibodies. Previous studies have demonstrated the ability of PPAD to citrullinate conventional RA-specific self-peptide targets, such as human fibrin(ogen), vimentin, and $\alpha$-enolase. ${ }^{153,154}$ The mode of citrullination by PPAD is distinct from human PAD isoforms in that it targets C-terminal arginine residues for deamination in proteins, whereas human PAD preferentially deaminates internal arginine residues. ${ }^{155}$ PPAD is also not $\mathrm{Ca}^{2+}$ dependent like human PAD isoforms. ${ }^{156}$

The major bacterial co-virulence factor of PPAD secreted by $P$. gingivalis is a class of proteolytic enzymes termed gingipains. Gingipains catalyze the cleavage of proteins or peptides at either lysine or arginine residues. ${ }^{155}$ Arginine-specific gingipains (RgpA or RgpB) yield suitable peptide fragments with Cterminal Arginine residues for citrullination by PPAD. ${ }^{155-157}$ RgpB has been shown to effectively cleave arginine residues in fibrinogen, with PPAD able to execute citrullination of the majority of resulting peptide fragments. ${ }^{158}$ PPAD and Rgp are both expressed on the outer membrane of $P$. gingivalis, and operate in concert to elicit autoimmune inflammatory responses in the human host. ${ }^{154,156}$

Positive correlations between serum levels of anti-PPAD antibodies with CRP and IL- 6 indicate a role of $P$. gingivalis infection in producing systemic inflammation. ${ }^{80}$ Yamakawa et al demonstrated that $P$. gingivalis infection of the spontaneous keratoconus (SKC) mouse model produces rapid RA development, with significant increases in arthritis score, APCAs, proinflammatory signaling molecules, and a decrease in bone density observed. ${ }^{159}$ PPAD citrullination of histone proteins aids $P$. gingivalis in evading neutrophil extracellular traps (NETs). ${ }^{152} P$. gingivalis in turn can induce NETosis. ${ }^{160}$ The development of arthritis through $P$. gingivalis-induced inflammatory lesions has been demonstrated in an animal model. ${ }^{161}$

The activity of $P$. gingivalis and its virulence factors may also contribute to the increased cardiovascular disease risk in RA and Parkinson's disease (PD) patients. ${ }^{162,163}$ It has been demonstrated that Arginine-specific gingipains (RgpA, $\mathrm{RgpB}$ ) are able to activate the coagulation cascade at multiple levels. Gingipains proteolytically stimulate coagulation factors IX, ${ }^{164} \mathrm{X},{ }^{165}$ and II (prothrombin). ${ }^{166}$ However, unstable fibrin clots are formed as a result of concurrent fibrinogen degradation by lysine-gingipains (Kgp). ${ }^{167}$ The proteolytic activities of the virulence factors of $P$. gingivalis have been shown to degrade apolipoproteins essential for normal lipoprotein metabolism, producing proinflammatory and proarthritogenic events that could account for increased risk of atherosclerosis. ${ }^{162}$ The proteolysis of human fibrinogen through the combined effect of PPAD and RgpB inhibits 
fibrin polymerization, which results in localized bleeding and a potentially dysregulated coagulation cascade. ${ }^{168}$ Rgp is able to activate platelets via platelet activation receptors one (PAR-1) and four (PAR-4). ${ }^{169}$ Activation of PARs by gingipains is similar to platelet activation by thrombin, as gingipains target $\mathrm{N}$-terminal regions of PARs that contain cleavage sites for thrombin. ${ }^{151}$

Recently, LPS and gingipains from $P$. gingivalis were also shown to cause amyloid formation in purified fibrinogen. ${ }^{170}$ The presence of gingipains in whole blood clots as detected by a fluorescent anti-RgpA antibody was confirmed in a PD patient population, and this was associated with increased levels of circulating proinflammatory cytokines, hypercoagulation, amyloid fibrin formation, and altered platelet ultrastruc- ture. ${ }^{170}$ These findings could therefore also be observable within RA patient sera, as the presence of $P$. gingivalis and its associated gingipains has a long-established relationship with disease as well. - Fig. 4 illustrates the human coagulation cascade, indicating the effects RA-specific inflammatory and autoimmune events may have on overall hemostatic outcome.

\section{RA Inflammatory Pathways: Interactions between Citrullinated Fibrinogen and Prominent Immune Cells}

The chronic inflammatory state that is a hallmark of RA is characterized by an accumulation of inflammatory leukocytes into the synovium and articular spaces. ${ }^{54,171}$ The

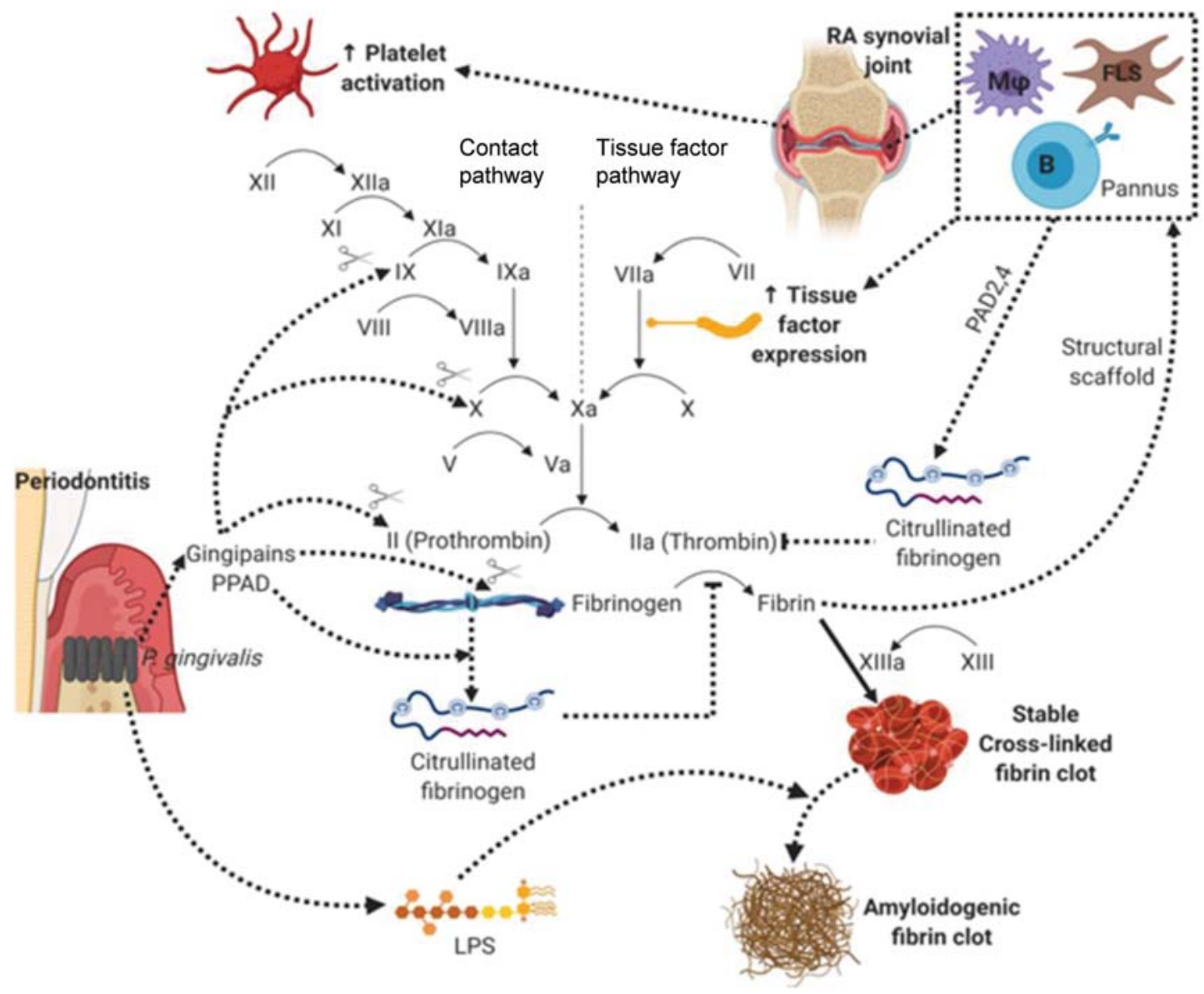

Chart key

PPAD: Porphyromonas gingivalis peptidylarginine deaminase PAD: peptidylarginine deaminase

B: B lymphocyte $\mathbf{M} \varphi$ : Macrophage FLS: Fibroblast-like synoviocyte LPS: lipopolysaccharide Physiological hemostasis reactions

RA-specific interferences with hemostasis

Fig. 4 Chronic synovitis and invasive pannus formation, characteristic of clinical rheumatoid arthritis (RA), may result in the amplification of coagulation by increased stimulation of clotting components in both the contact pathway (heightened activated platelet phenotype) and tissue factor pathway (enhanced tissue factor expression by immune cells). Insoluble fibrin in return acts as a structural scaffold agent for pannus formation in RA synovial joints. Activation of coagulation may also be proteolytically propagated by Porphyromonas gingivalis virulence factors (gingipains) at various levels. However, previous studies have demonstrated that citrullinated fibrinogen is not able to undergo thrombin digestion and subsequent fibrin polymerization. It has also been shown that LPS from gram-negative bacteria (such as $P$. gingivalis) is able to inflict fibrin alteration that are amyloid in nature, resulting in structurally unstable clots. (Original figure; created with Biorender.com). 
cellular composition of inflamed RA synovium consists of immune cells from both innate and humoral systems, fibroblast-like synoviocytes, chondrocytes, and bone-remodeling cells such as osteoclasts and osteoblasts. ${ }^{54}$

The RA autoimmune response is likely elicited due to an abnormal humoral response to the presence of citrullinated proteins in affected individuals. ${ }^{172}$ The major genetic risk factor for RA ACPA generation, HLA-DR $\beta 1$ "shared epitope" alleles, exerts major influence on $\alpha \beta C D 4^{+}$T-cell selection. ${ }^{11,173}$ The altered $\mathrm{CD} 4^{+} \mathrm{T}$-cell repertoire is responsible for inflammatory signaling and generation of anticitrullinated autoantibodies by synovial B-cells through the self-presentation of citrullinated proteins by MHC molecules (-Fig. 5). ${ }^{11}$ Deaminating enzymes responsible for generation of citrullinated antigens (PAD2 and PAD4) are also expressed by inflammatory leukocytes within the synovial microenvironment, which include synovial $\mathrm{T}$ and $\mathrm{B}$ cells, macrophages, neutrophils, and fibroblastlike synoviocytes ${ }^{174,175}$

Human fibrin(ogen) is capable of directly stimulating a variety of leukocyte activities (-Fig. 6). Fibrin(ogen) engagement with macrophages via TLR- 4 and other integrins induces expression of proinflammatory chemokines, ${ }^{176}$ and cytokines such as TNF- $\alpha .{ }^{177}$ Fibrinogen stimulates the proinflammatory activity of neutrophils by binding to the $\alpha$-subunit of CD11b/ CD18. ${ }^{178}$ Fibrinogen regulates NFKB signaling and inflammatory chemokine expression of endothelial cells. ${ }^{179}$ Human synovial fibroblasts express ICAM-1 and inflammatory chemokines under the influence of fibrinogen. ${ }^{180}$ These findings indicate that fibrin(ogen), which is present in high amounts within RA articular spaces, may fulfil a pronounced role in mediating various RA-related inflammatory processes. Fibrin displays even stronger involvement in propagation of inflammatory processes in RA than its soluble precursor. ${ }^{117}$ Fibrin deposits are present within the RA synovial tissue lining, and thus enable the proliferation of RA synovial fibroblasts and local cytokine release. ${ }^{44,181}$ The insoluble nature of the protein increases the difficulty of its clearance from articular spaces, thus leading to increased likelihood of posttranslational modifications and generation of an autoimmune inflammatory response. $^{117}$

\section{Macrophages/Monocytes}

ACPAs directly contribute to initiating and sustaining the state of synovial inflammation by their ability to activate monocytes and macrophages, to produce inflammatory cytokines. ${ }^{182}$ Citrullinated-fibrinogen containing immune complexes stimulate TNF $\alpha$ secretion by macrophages through FcrR-TLR4 engagement. ${ }^{108,183}$ The presence of ACPAs causes a dysregulated M1/M2 macrophage subset polarization, favoring M1 (classical) activation. ${ }^{184}$ The M1 subset is characterized by its inflammatory, microbicidal, and tumoricidal properties. ${ }^{184}$ There is an overexpression of TLR2 and TLR4 receptors by macrophages and synovial fibroblasts in RA. ${ }^{117}$ TLRs recognize disease-associated molecular patterns (DAMPs) and PAMPs, resulting in innate immune responses. ${ }^{185}$ PAMPs are microbial-derived molecules such as peptidoglycan, bacterial and viral deoxyribonucleic acid (DNA) that are structurally distinguish- able from host molecules. ${ }^{185,186}$ DAMPs are derived from clinical symptoms associated with the pathophysiological responses, with fibrinogen/fibrin and dsRNA from apoptotic cells present in the RA joint serving as DAMPs. ${ }^{185,186}$

\section{RA Synovial Fibroblasts}

The porous structural arrangement of the synovial lining that lacks epithelial cells, basement membranes, tight junctions, or desmosomes allows accumulation of immune complexes and bacterial cell wall components within rheumatic joints. ${ }^{187}$ The synovial intimal lining layer consists of two distinct cell typesmacrophage-like synoviocytes (Type A) and fibroblast-like synoviocytes (Type B). ${ }^{187}$ The inflammatory milieu of the RA synovium transforms the surrounding tissues to become increasingly hyperplastic, invasive, and immunogenic. ${ }^{187}$ Transcription factor NFKB is ubiquitously expressed in monocytes and synovial fibroblasts, and regulates the expression of proinflammatory cytokines, chemokines, and adhesion molecules in RA. ${ }^{188}$ There is an overexpression of TLRs in RA synovial fibroblasts (RASF), with both fibrin deposits in the RA joint and soluble fibrinogen acting as candidate TLR ligands. ${ }^{44,186}$ TLR ligation potentiates the inflammatory cytokine production of RASFs, with prominent secreted mediators including IL-6, IL-8, TNF $\alpha$, MMPs, and vascular endothelial growth factor (VEGF). ${ }^{186}$ Citrullination of peptides further amplifies the proinflammatory potential of RASFs, with a significant increase in cytokine secretion. ${ }^{117}$

\section{Tumor Necrosis Factor: Apical RA Cytokine}

TNF $\alpha$ is considered the most prominent cytokine involved in the RA inflammatory response, as it in turn stimulates further monocyte and macrophage activity and proinflammatory cytokine release. ${ }^{189-191}$ TNF $\alpha$ has been demonstrated to be increased by $62 \%$ in RA patient sera compared with controls. ${ }^{192}$ The suggested importance of TNF $\alpha$ in RA pathogenesis has been highlighted by the relative efficacy of TNF $\alpha$ inhibitor (infliximab) treatment in the attenuation of disease symptoms and synovial inflammation. ${ }^{193,194}$ TNF $\alpha$ is produced by $\mathrm{T}$ cells within the synovial lining, local macrophages, and monocytes resulting in chronic synovitis and activates osteoclasts and MMPs leading to cartilage and bone destruction. ${ }^{195,196}$ TNF $\alpha$ is also able to activate platelets through the arachidonic pathway, with platelets further propagating RA synovial inflammation and the associated risk of thrombotic cardiovascular events. ${ }^{197}$ The chronic exposure of synovial T-cells to TNF $\alpha$ leads to decreased immune tolerance and unresponsiveness to TNF $\alpha$ inhibitor treatment (prevalent in 30-40\% of RA patients). ${ }^{191}$

\section{Neutrophils and NETosis}

The presence of hyperactive neutrophils in RA synovial fluid and pannus tissue, in particular NETosis (formation of neutrophil extracellular traps or NETs), has been confirmed by multiple studies. ${ }^{198-200}$ NETs are chromatin-derived extracellular snares that are externalized from neutrophils in response to microbial infections or inflammation. ${ }^{201} \mathrm{Neu}-$ trophils and NETosis are key components in the perpetual inflammatory response encountered in RA patients. 


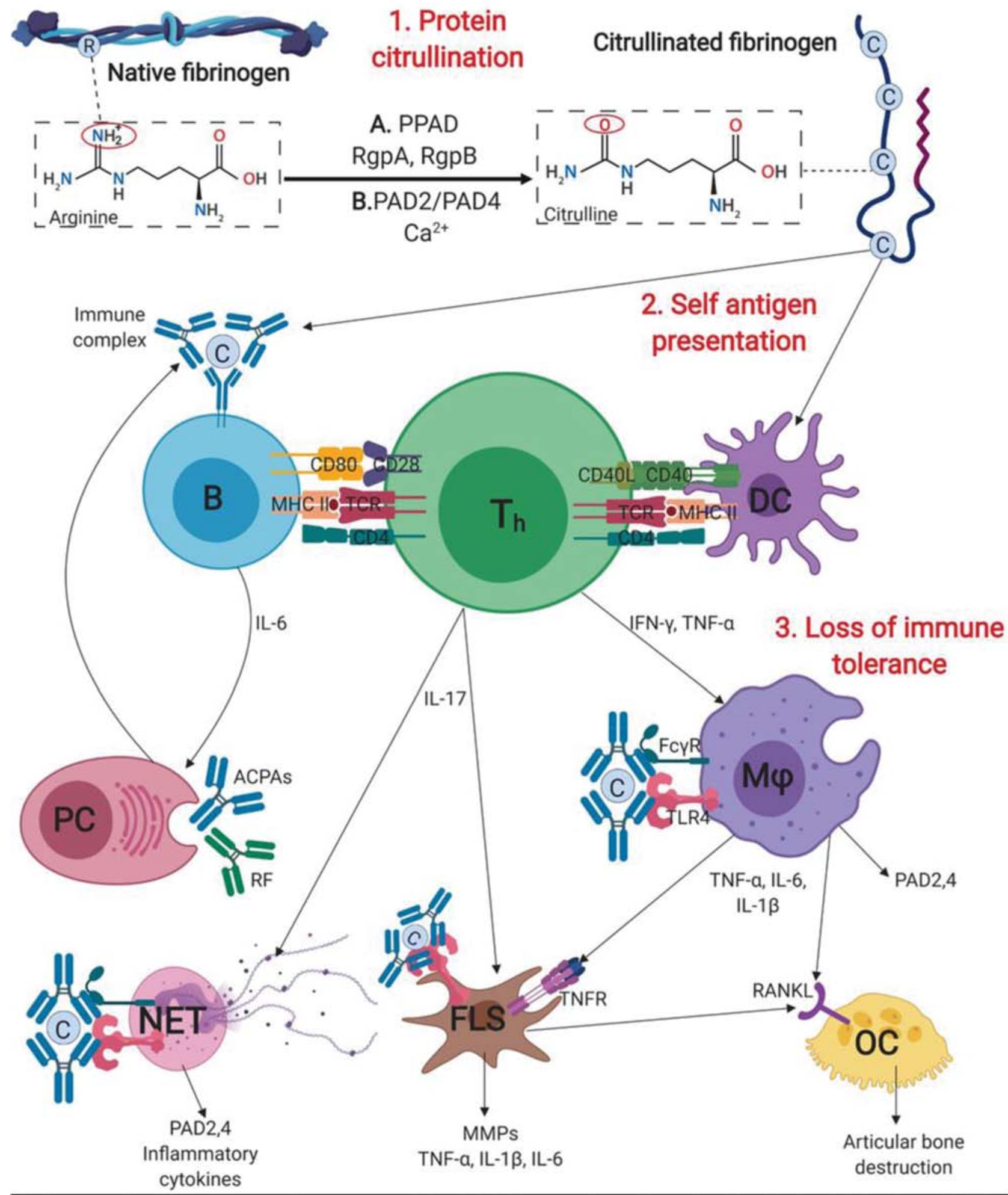

\section{Chart key}

B: B lymphocyte Th: Naïve T-helper lymphocyte DC: Dendritic cell $M \varphi$ : Macrophage NET: Neutrophil extracellular trap PC: Plasma cell FLS: Fibroblast-like synoviocyte OC: Osteoclast

Fig. 5 The rheumatoid arthritis (RA) "shared epitope" risk gene results in citrullinated proteins being presented as self-antigens via MHC-II complexes to CD4+ T-helper cells, resulting in a breakdown of immune tolerance to the presence of citrullinated proteins, with T-lymphocyte differentiation resulting in the production of RA-specific autoantibodies (ACPAs and RFs), as well as direct stimulation of inflammatory effector cells via cytokine signaling. ACPAs, anticitrullinated protein antibodies; MHC, major histocompatibility complex; RF, rheumatoid factor (Original figure; created with Biorender.com). 


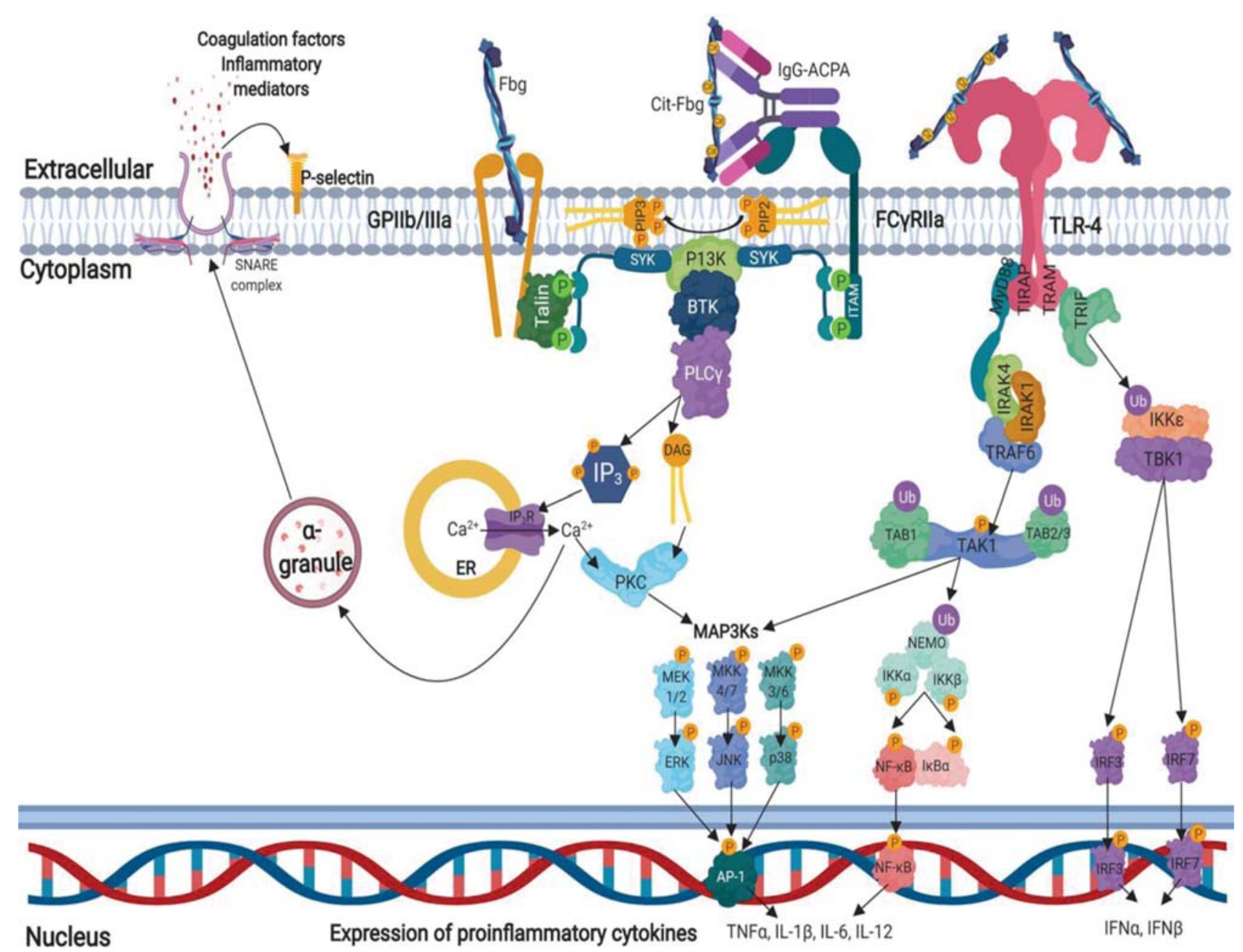

Fig. 6 The prominent cell surface receptors recognized as ligating with human fibrinogen, citrullinated fibrinogen, and citrullinated-fibrinogen immune complexes and their downstream signaling pathways are summarized. (Original figure; created with Biorender.com).

Neutrophils express multiple cell surface receptors, and NETosis is induced by proinflammatory mediators such as bacterial LPS, ${ }^{202}$ platelet TLR- $4,{ }^{203}$ and cytokines such as TNF $\alpha$, IL-1 $\beta$, and IL-8. ${ }^{204}$ Enhanced NETosis is associated with local and peripheral presence of ACPAs, with NETs prominent sources of citrullinated autoantigens that express high levels of PAD2 and PAD4 enzymes. ${ }^{205}$ NETs along with their individual components (DNA and histones) have also been shown to possess significant prothrombotic and antifibrinolytic properties, and have been discussed at length in a recent review by Varjú and Kolev. ${ }^{206}$ NETs provide a platform for the accumulation of integral hemostatic components such as platelets, erythrocytes, von Willebrand factor, and fibrinogen. ${ }^{207}$ Histones promote fibrin deposition through its ability to bind to and inactivate antithrombin. ${ }^{208}$ This protective mechanism against the inhibitory effects of antithrombin is also achieved by the citrullination of antithrombin by PAD4. ${ }^{209}$ Integration of DNA-histone complexes into fibrin networks results in thicker fibrin fibers that consequently improve clot stability and rigidity but decreases clot permeability. ${ }^{208,210}$ The presence of these NET-derived complexes within the fibrin network also impedes fibrinolysis, through the ability of both histones and DNA to bind large fibrin degradation products (such as plasminogen) and inhibit its activity. $^{208,210}$

\section{Conclusion}

In this review, we have discussed in detail the role that specific plasma proteins play at every stage of RA immunopathogenic progression. All major themes and the clinical relevance considered in this review are summarized in - Table 1. Endogenous and exogenous sources of protein citrullination, coupled with the genetic propensity to present citrullinated antigens to $\mathrm{CD} 4^{+} \mathrm{T}$-lymphocytes present the most convincing current paradigm to explain the development of RA autoimmunity. The insoluble clotting protein fibrin, along with its soluble precursor fibrinogen, has been demonstrated as prime targets for PAD citrullination and the generation of fibrin(ogen)-specific autoantibodies in RA. The excessive rate of fibrin generation and breakdown in the RA synovium actively contributes to RA pannus structure and inflammatory signaling. Both native and citrullinated forms of fibrin(ogen) have been shown to interact with and regulate the proinflammatory activities of various immune cells in RA, including macrophages, 
Table 1 Key points of this review

- To date, a combination of genetic risk, the presence of infectious agents, including those that become dormant within the host, along with certain environmental exposures present the most plausible etiological explanation for the development of clinical rheumatoid arthritis (RA) disease.

- Ebringer's theory (with experiments) states that Proteus infection from the urinary tract is a major cause of RA. Also, the periodontal pathogen Porphyromonas gingivalis possibly presents a major exogenous contributor to RA autoimmune generation through the expression of its unique virulence factors.

- In addition to destructive synovitis, a high risk of cardiovascular disease as a result of dysregulated thromboinflammatory function is well established in RA patients.

- The presence of autoantibodies directed toward citrullinated proteins (ACPAs) is highly correlated with disease development and influences various proinflammatory processes.

- Human fibrin(ogen), a key component of the coagulation process, is a prime candidate ligand for citrullination by peptidylarginine deaminase (PAD) enzymes.

- Further research is necessary to define the involvement of citrullination with regards to the formation of abnormal fibrin clots observed in RA patients.

Clinical relevance

- Infections of certain mucosal tissues and bacterial components are important factors for consideration in the possible prevention, diagnosis, and treatment of RA.

- Acute phase proteins, such as fibrinogen and serum amyloid $\mathrm{A}$, present significant clinical value due to their involvement at various levels of disease development.

- By monitoring highly sensitive markers of thrombotic function in RA patients through an individualized medicine approach may represent an improved diagnostic and treatment strategy for systemic inflammation and secondary cardiovascular disease.

synovial fibroblasts, and neutrophils. The increased CVD risk in RA is independent of traditional risk factors, and the interactions between dysregulated inflammatory and hemostatic processes present a major contribution to this secondary disease complication. The extent to which the protein modification processes of citrullination and amyloidogenesis of fibrinogen may interact and influence the other represents an area of novel research that could explain the presence of excessive and aberrant clot formation in RA patients. $\beta$-amyloid formation of fibrin fibers as a result of increased A-SAA levels and bacterial LPS constitutes additional coagulopathic complications in RA patients. Despite observations of increased thrombotic tendency coupled with structurally abnormal fibrin clot formation in RA patients, the exact role that citrullinated proteins fulfil in this regard remains controversial and requires further investigation. The contribution of bacterial LPS to the generation of autoantibodies in RA is also yet to be determined. Whether LPS could directly stimulate increased rates of protein citrullination as a result of perhaps autocrine TNF $\alpha$-induced apoptosis of immune cells, ${ }^{211}$ or through indirect mechanisms certainly warrants further investigation. Furthermore, it is yet be determined how free LPS in circulation might interact directly with plasma proteins like fibrinogen which can lead to citrullination, amyloid formation, and anomalous blood clot formation.

To conclude, it is suggested that specific proteins involved in chronic synovitis and thrombotic tendency in RA patients, such as fibrin(ogen) and amyloid A proteins be considered more intensively in research. The extensive signaling processes these proteins are involved with regards to disease development may present novel areas for identifying potential diagnostic biomarkers and therapeutic interventions.

Conflicts of Interest

None.

\section{References}

1 Scott DL, Wolfe F, Huizinga TW. Rheumatoid arthritis. Lancet 2010;376(9746):1094-1108

2 Silman AJ. Epidemiology of rheumatoid arthritis. APMIS 1994; 102(10):721-728

3 Tedeschi SK, Bermas B, Costenbader KH. Sexual disparities in the incidence and course of SLE and RA. Clin Immunol 2013;149(02): 211-218

4 Pratesi F, Panza F, Paolini I, et al. Fingerprinting of anti-citrullinated protein antibodies (ACPA): specificity, isotypes and subclasses. Lupus 2015;24(4-5):433-441

5 van der Woude D, Catrina AI. HLA and anti-citrullinated protein antibodies: building blocks in RA. Best Pract Res Clin Rheumatol 2015;29(06):692-705

6 Smolen JS, Breedveld FC, Eberl G, et al. Validity and reliability of the twenty-eight-joint count for the assessment of rheumatoid arthritis activity. Arthritis Rheum 1995;38(01):38-43

7 Sokka T. Work disability in early rheumatoid arthritis. Clin Exp Rheumatol 2003;21(05, Suppl 31):S71-S74

8 Klareskog L, Rönnelid J, Lundberg K, Padyukov L, Alfredsson L. Immunity to citrullinated proteins in rheumatoid arthritis. Annu Rev Immunol 2008;26:651-675

9 Ärlestig L, Mullazehi M, Kokkonen H, Rocklöv J, Rönnelid J, Dahlqvist SR. Antibodies against cyclic citrullinated peptides of IgG, IgA and IgM isotype and rheumatoid factor of IgM and IgA isotype are increased in unaffected members of multicase rheumatoid arthritis families from northern Sweden. Ann Rheum Dis 2012;71(06):825-829 
10 Kolfenbach JR, Deane KD, Derber LA, et al. A prospective approach to investigating the natural history of preclinical rheumatoid arthritis (RA) using first-degree relatives of probands with RA. Arthritis Rheum 2009;61(12):1735-1742

11 Roudier J. Association of MHC and rheumatoid arthritis. Association of RA with HLA-DR4: the role of repertoire selection. Arthritis Res 2000;2(03):217-220

12 Picchianti-Diamanti A, Rosado MM, D'Amelio R. Infectious agents and inflammation: the role of microbiota in autoimmune arthritis. Front Microbiol 2018;8:2696

13 Salmi M, Andrew DP, Butcher EC, Jalkanen S. Dual binding capacity of mucosal immunoblasts to mucosal and synovial endothelium in humans: dissection of the molecular mechanisms. J Exp Med 1995;181(01):137-149

14 Rashid T, Ebringer A. Rheumatoid arthritis is linked to Proteusthe evidence. Clin Rheumatol 2007;26(07):1036-1043

15 Tishler M, Caspi D, Almog Y, Segal R, Yaron M. Increased incidence of urinary tract infection in patients with rheumatoid arthritis and secondary Sjögren's syndrome. Ann Rheum Dis 1992;51(05):604-606

16 Senior BW, Anderson GA, Morley KD, Kerr MA. Evidence that patients with rheumatoid arthritis have asymptomatic 'nonsignificant' Proteus mirabilis bacteriuria more frequently than healthy controls. J Infect 1999;38(02):99-106

17 Ebringer A, Cunningham P, Ahmadi K, Wrigglesworth J, Hosseini R, Wilson C. Sequence similarity between HLA-DR1 and DR4 subtypes associated with rheumatoid arthritis and proteus/serratia membrane haemolysins. Ann Rheum Dis 1992;51(11):1245-1246

18 Rashid T, Tiwana H, Wilson C, Ebringer A. Rheumatoid arthritis as an autoimmune disease caused by Proteus urinary tract infections: a proposal for a therapeutic protocol. Isr Med Assoc J 2001; 3(09):675-680

19 Alexander C, Rietschel ET. Bacterial lipopolysaccharides and innate immunity. J Endotoxin Res 2001;7(03):167-202

20 Benoit R, Rowe S, Watkins SC, et al. Pure endotoxin does not pass across the intestinal epithelium in vitro. Shock 1998;10(01): 43-48

21 Guo S, Al-Sadi R, Said HM, Ma TY. Lipopolysaccharide causes an increase in intestinal tight junction permeability in vitro and in vivo by inducing enterocyte membrane expression and localization of TLR-4 and CD14. Am J Pathol 2013;182(02):375-387

22 Maeda Y, Kumanogoh A, Takeda K. Altered composition of gut microbiota in rheumatoid arthritis patients. Nihon Rinsho Meneki Gakkai Kaishi 2016;39(01):59-63

23 Zhang $\mathrm{X}$, Zhang D, Jia $\mathrm{H}$, et al. The oral and gut microbiomes are perturbed in rheumatoid arthritis and partly normalized after treatment. Nat Med 2015;21(08):895-905

24 Lu YC, Yeh WC, Ohashi PS. LPS/TLR4 signal transduction pathway. Cytokine 2008;42(02):145-151

25 Koch L, Hofer S, Weigand MA, Frommhold D, Poeschl J. Lipopolysaccharide-induced activation of coagulation in neonatal cord and adult blood monitored by thrombelastography. Thromb Res 2009;124(04):463-467

26 Landsem A, Fure H, Christiansen D, et al. The key roles of complement and tissue factor in Escherichia coli-induced coagulation in human whole blood. Clin Exp Immunol 2015;182(01): 81-89

27 Pretorius E, Mbotwe S, Bester J, Robinson CJ, Kell DB. Acute induction of anomalous and amyloidogenic blood clotting by molecular amplification of highly substoichiometric levels of bacterial lipopolysaccharide. J R Soc Interface 2016;13(122): 20160539

28 Pretorius E, Akeredolu OO, Soma P, Kell DB. Major involvement of bacterial components in rheumatoid arthritis and its accompanying oxidative stress, systemic inflammation and hypercoagulability. Exp Biol Med (Maywood) 2017;242(04):355-373

29 Aviña-Zubieta JA, Choi HK, Sadatsafavi M, Etminan M, Esdaile JM, Lacaille D. Risk of cardiovascular mortality in patients with rheumatoid arthritis: a meta-analysis of observational studies. Arthritis Rheum 2008;59(12):1690-1697

30 Maradit-Kremers H, Nicola PJ, Crowson CS, Ballman KV, Gabriel SE. Cardiovascular death in rheumatoid arthritis: a populationbased study. Arthritis Rheum 2005;52(03):722-732

31 McEntegart A, Capell HA, Creran D, Rumley A, Woodward M, Lowe GD. Cardiovascular risk factors, including thrombotic variables, in a population with rheumatoid arthritis. Rheumatology (Oxford) 2001;40(06):640-644

32 del Rincón ID, Williams K, Stern MP, Freeman GL, Escalante A. High incidence of cardiovascular events in a rheumatoid arthritis cohort not explained by traditional cardiac risk factors. Arthritis Rheum 2001;44(12):2737-2745

33 Gallistl S, Mangge H, Neuwirth G, Muntean W. Activation of the haemostatic system in children with juvenile rheumatoid arthritis correlates with disease activity. Thromb Res 1998;92(06):267-272

34 Kwasny-Krochin B, Gluszko P, Undas A. Unfavorably altered fibrin clot properties in patients with active rheumatoid arthritis. Thromb Res 2010;126(01):e11-e16

35 So AK, Varisco PA, Kemkes-Matthes B, et al. Arthritis is linked to local and systemic activation of coagulation and fibrinolysis pathways. J Thromb Haemost 2003;1(12):2510-2515

36 Habets KL, Trouw LA, Levarht EW, et al. Anti-citrullinated protein antibodies contribute to platelet activation in rheumatoid arthritis. Arthritis Res Ther 2015;17(01):209

37 Henn V, Slupsky JR, Gräfe M, et al. CD40 ligand on activated platelets triggers an inflammatory reaction of endothelial cells. Nature 1998;391(6667):591-594

38 Amelot AA, Tagzirt M, Ducouret G, Kuen RL, Le Bonniec BF. Platelet factor 4 (CXCL4) seals blood clots by altering the structure of fibrin. J Biol Chem 2007;282(01):710-720

39 Wohner N. Role of cellular elements in thrombus formation and dissolution. Cardiovasc Hematol Agents Med Chem 2008;6(03): 224-228

40 Chen J, Bierhaus A, Schiekofer S, et al. Tissue factor-a receptor involved in the control of cellular properties, including angiogenesis. Thromb Haemost 2001;86(01):334-345

41 Chen L, Lu Y, Chu Y, Xie J, Ding W, Wang F. Tissue factor expression in rheumatoid synovium: a potential role in pannus invasion of rheumatoid arthritis. Acta Histochem 2013;115(07): 692-697

42 Mantovani A, Sozzani S, Vecchi A, Introna M, Allavena P. Cytokine activation of endothelial cells: new molecules for an old paradigm. Thromb Haemost 1997;78(01):406-414

43 Pretorius E, Oberholzer HM, van der Spuy WJ, Swanepoel AC, Soma P. Scanning electron microscopy of fibrin networks in rheumatoid arthritis: a qualitative analysis. Rheumatol Int 2012;32(06):1611-1615

44 Sánchez-Pernaute O, Largo R, Calvo E, Alvarez-Soria MA, Egido J, Herrero-Beaumont G. A fibrin based model for rheumatoid synovitis. Ann Rheum Dis 2003;62(12):1135-1138

45 Masson-Bessière C, Sebbag M, Durieux JJ, et al. In the rheumatoid pannus, anti-filaggrin autoantibodies are produced by local plasma cells and constitute a higher proportion of IgG than in synovial fluid and serum. Clin Exp Immunol 2000;119(03):544-552

46 Sebbag M, Moinard N, Auger I, et al. Epitopes of human fibrin recognized by the rheumatoid arthritis-specific autoantibodies to citrullinated proteins. Eur J Immunol 2006;36(08):2250-2263

47 Falkenburg WJ, van Schaardenburg D, Ooijevaar-de Heer P, Wolbink G, Rispens T. IgG subclass specificity discriminates restricted IgM rheumatoid factor responses from more mature anti-citrullinated protein antibody-associated or isotype-switched IgA responses. Arthritis Rheumatol 2015;67(12):3124-3134

48 Egeland T, Munthe E. The role of the laboratory in rheumatology. Rheumatoid factors. Clin Rheum Dis 1983;9(01):135-160

49 Trier NH, Holm BE, Heiden J, et al. The use of synthetic peptides for detection of anti-citrullinated protein antibodies in rheumatoid arthritis. J Immunol Methods 2018;454:6-14 
50 Nishimura K, Sugiyama D, Kogata Y, et al. Meta-analysis: diagnostic accuracy of anti-cyclic citrullinated peptide antibody and rheumatoid factor for rheumatoid arthritis. Ann Intern Med 2007;146(11):797-808

51 Lingampalli N, Sokolove J, Lahey LJ, et al. Combination of anticitrullinated protein antibodies and rheumatoid factor is associated with increased systemic inflammatory mediators and more rapid progression from preclinical to clinical rheumatoid arthritis. Clin Immunol 2018;195:119-126

52 Bugatti S, Bogliolo L, Vitolo B, Manzo A, Montecucco C, Caporali R. Anti-citrullinated protein antibodies and high levels of rheumatoid factor are associated with systemic bone loss in patients with early untreated rheumatoid arthritis. Arthritis Res Ther 2016;18(01):226

53 Trela M, Perera S, Sheeran T, Rylance P, Nelson PN, Attridge K. Citrullination facilitates cross-reactivity of rheumatoid factor with non-IgG1 Fc epitopes in rheumatoid arthritis. Sci Rep 2019; 9(01):12068

54 Nevius E, Gomes AC, Pereira JP. Inflammatory cell migration in rheumatoid arthritis: a comprehensive review. Clin Rev Allergy Immunol 2016;51(01):59-78

55 Raijmakers R, van Beers JJ, El-Azzouny M, et al. Elevated levels of fibrinogen-derived endogenous citrullinated peptides in synovial fluid of rheumatoid arthritis patients. Arthritis Res Ther 2012;14(03):R114

56 Tarcsa E, Marekov LN, Mei G, Melino G, Lee SC, Steinert PM. Protein unfolding by peptidylarginine deiminase. Substrate specificity and structural relationships of the natural substrates trichohyalin and filaggrin. J Biol Chem 1996;271(48):30709-30716

57 Masson-Bessière C, Sebbag M, Girbal-Neuhauser E, et al. The major synovial targets of the rheumatoid arthritis-specific antifilaggrin autoantibodies are deiminated forms of the alpha- and beta-chains of fibrin. J Immunol 2001;166(06):4177-4184

58 Hagiwara T, Hidaka Y, Yamada M. Deimination of histone H2A and $\mathrm{H} 4$ at arginine 3 in HL-60 granulocytes. Biochemistry 2005; 44(15):5827-5834

59 Vossenaar ER, Després N, Lapointe E, et al. Rheumatoid arthritis specific anti-Sa antibodies target citrullinated vimentin. Arthritis Res Ther 2004;6(02):R142-R150

60 Kinloch A, Tatzer V, Wait R, et al. Identification of citrullinated alpha-enolase as a candidate autoantigen in rheumatoid arthritis. Arthritis Res Ther 2005;7(06):R1421-R1429

61 Burkhardt H, Sehnert B, Bockermann R, Engström A, Kalden JR, Holmdahl R. Humoral immune response to citrullinated collagen type II determinants in early rheumatoid arthritis. Eur J Immunol 2005;35(05):1643-1652

62 Suzuki A, Yamada R, Ohtake-Yamanaka M, Okazaki Y, Sawada T, Yamamoto K. Anti-citrullinated collagen type I antibody is a target of autoimmunity in rheumatoid arthritis. Biochem Biophys Res Commun 2005;333(02):418-426

63 Hill JA, Southwood S, Sette A, Jevnikar AM, Bell DA, Cairns E. Cutting edge: the conversion of arginine to citrulline allows for a high-affinity peptide interaction with the rheumatoid arthritisassociated HLA-DRB ${ }^{*} 0401$ MHC class II molecule. J Immunol 2003;171(02):538-541

64 Suwannalai P, Trouw LA, Toes RE, Huizinga TW. Anti-citrullinated protein antibodies (ACPA) in early rheumatoid arthritis. Mod Rheumatol 2012;22(01):15-20

65 Rantapää-Dahlqvist S, de Jong BA, Berglin E, et al. Antibodies against cyclic citrullinated peptide and IgA rheumatoid factor predict the development of rheumatoid arthritis. Arthritis Rheum 2003;48(10):2741-2749

66 Nielen MM, van Schaardenburg D, Reesink HW, et al. Specific autoantibodies precede the symptoms of rheumatoid arthritis: a study of serial measurements in blood donors. Arthritis Rheum 2004;50(02):380-386

67 Klareskog L, Catrina AI, Paget S. Rheumatoid arthritis. Lancet 2009;373(9664):659-672
68 Vossenaar ER, Zendman AJ, van Venrooij WJ, Pruijn GJ. PAD, a growing family of citrullinating enzymes: genes, features and involvement in disease. BioEssays 2003;25(11):1106-1118

69 Asaga $H$, Yamada M, Senshu T. Selective deimination of vimentin in calcium ionophore-induced apoptosis of mouse peritoneal macrophages. Biochem Biophys Res Commun 1998;243(03):641-646

70 Schwab BL, Guerini D, Didszun C, et al. Cleavage of plasma membrane calcium pumps by caspases: a link between apoptosis and necrosis. Cell Death Differ 2002;9(08):818-831

71 Szekanecz Z, Soós L, Szabó Z, et al. Anti-citrullinated protein antibodies in rheumatoid arthritis: as good as it gets? Clin Rev Allergy Immunol 2008;34(01):26-31

72 Puszczewicz M, Iwaszkiewicz C. Role of anti-citrullinated protein antibodies in diagnosis and prognosis of rheumatoid arthritis. Arch Med Sci 2011;7(02):189-194

73 Farid SSh, Azizi G, Mirshafiey A. Anti-citrullinated protein antibodies and their clinical utility in rheumatoid arthritis. Int J Rheum Dis 2013;16(04):379-386

74 Chang X, Xia Y, Pan J, Meng Q, Zhao Y, Yan X. PADI2 is significantly associated with rheumatoid arthritis. PLoS One 2013;8(12): e81259

75 Damgaard D, Bawadekar M, Senolt L, Stensballe A, Shelef MA, Nielsen $\mathrm{CH}$. Relative efficiencies of peptidylarginine deiminase 2 and 4 in generating target sites for anti-citrullinated protein antibodies in fibrinogen, alpha-enolase and histone H3. PLoS One 2018;13(08):e0203214

76 Holers VM. Autoimmunity to citrullinated proteins and the initiation of rheumatoid arthritis. Curr Opin Immunol 2013;25 (06):728-735

77 Bang SY, Lee KH, Cho SK, Lee HS, Lee KW, Bae SC. Smoking increases rheumatoid arthritis susceptibility in individuals carrying the HLA-DRB1 shared epitope, regardless of rheumatoid factor or anti-cyclic citrullinated peptide antibody status. Arthritis Rheum 2010;62(02):369-377

78 Mikuls TR, Payne JB, Yu F, et al. Periodontitis and Porphyromonas gingivalis in patients with rheumatoid arthritis. Arthritis Rheumatol 2014;66(05):1090-1100

79 Mikuls TR, Payne JB, Reinhardt RA, et al. Antibody responses to Porphyromonas gingivalis (P. gingivalis) in subjects with rheumatoid arthritis and periodontitis. Int Immunopharmacol 2009; 9(01):38-42

80 Shimada A, Kobayashi T, Ito S, et al. Expression of anti-Porphyromonas gingivalis peptidylarginine deiminase immunoglobulin $\mathrm{G}$ and peptidylarginine deiminase- 4 in patients with rheumatoid arthritis and periodontitis.J Periodontal Res 2016;51(01):103-111

81 Okada M, Kobayashi T, Ito S, et al. Periodontal treatment decreases levels of antibodies to Porphyromonas gingivalis and citrulline in patients with rheumatoid arthritis and periodontitis. J Periodontol 2013;84(12):e74-e84

82 Reparon-Schuijt CC, van Esch WJ, van Kooten C, et al. Secretion of anti-citrulline-containing peptide antibody by $B$ lymphocytes in rheumatoid arthritis. Arthritis Rheum 2001;44(01):41-47

83 Ioan-Facsinay A, el-Bannoudi $\mathrm{H}$, Scherer HU, et al. Anti-cyclic citrullinated peptide antibodies are a collection of anti-citrullinated protein antibodies and contain overlapping and non-overlapping reactivities. Ann Rheum Dis 2011;70(01):188-193

84 Snir O, Widhe M, von Spee C, et al. Multiple antibody reactivities to citrullinated antigens in sera from patients with rheumatoid arthritis: association with HLA-DRB1 alleles. Ann Rheum Dis 2009;68(05):736-743

85 Li S, Yu Y, Yue Y, et al. Autoantibodies from single circulating plasmablasts react with citrullinated antigens and Porphyromonas gingivalis in rheumatoid arthritis. Arthritis Rheumatol 2016; 68(03):614-626

86 Schellekens GA, de Jong BA, van den Hoogen FH, van de Putte LB, van Venrooij WJ. Citrulline is an essential constituent of antigenic determinants recognized by rheumatoid arthritis-specific autoantibodies. J Clin Invest 1998;101(01):273-281 
87 Chibnik LB, Mandl LA, Costenbader KH, Schur PH, Karlson EW. Comparison of threshold cutpoints and continuous measures of anti-cyclic citrullinated peptide antibodies in predicting future rheumatoid arthritis. J Rheumatol 2009;36(04):706-711

88 van de Stadt LA, van der Horst AR, de Koning MH, et al. The extent of the anti-citrullinated protein antibody repertoire is associated with arthritis development in patients with seropositive arthralgia. Ann Rheum Dis 2011;70(01):128-133

89 van der Woude D, Rantapää-Dahlqvist S, Ioan-Facsinay A, et al. Epitope spreading of the anti-citrullinated protein antibody response occurs before disease onset and is associated with the disease course of early arthritis. Ann Rheum Dis 2010;69 (08):1554-1561

90 Derksen VF, Ajeganova S, Trouw LA, et al. Rheumatoid arthritis phenotype at presentation differs depending on the number of autoantibodies present. Ann Rheum Dis 2017;76(04):716-720

91 van der Woude D, Syversen SW, van der Voort EI, et al. The ACPA isotype profile reflects long-term radiographic progression in rheumatoid arthritis. Ann Rheum Dis 2010;69(06):1110-1116

92 Aletaha D, Neogi T, Silman AJ, et al. 2010 rheumatoid arthritis classification criteria: an American College of Rheumatology/ European League Against Rheumatism collaborative initiative. Arthritis Rheum 2010;62(09):2569-2581

93 Nienhuis RL, Mandema E. A new serum factor in patients with rheumatoid arthritis; the antiperinuclear factor. Ann Rheum Dis 1964;23:302-305

94 Young BJ, Mallya RK, Leslie RD, Clark CJ, Hamblin TJ. Anti-keratin antibodies in rheumatoid arthritis. BMJ 1979;2(6182):97-99

95 Schellekens GA, Visser H, de Jong BA, et al. The diagnostic properties of rheumatoid arthritis antibodies recognizing a cyclic citrullinated peptide. Arthritis Rheum 2000;43(01):155-163

96 van Venrooij WJ, Hazes JM, Visser H. Anticitrullinated protein/peptide antibody and its role in the diagnosis and prognosis of early rheumatoid arthritis. Neth J Med 2002;60 (10):383-388

97 Okumura N, Haneishi A, Terasawa F. Citrullinated fibrinogen shows defects in FPA and FPB release and fibrin polymerization catalyzed by thrombin. Clin Chim Acta 2009;401(1-2):119-123

98 Nakayama-Hamada M, Suzuki A, Furukawa H, Yamada R, Yamamoto K. Citrullinated fibrinogen inhibits thrombin-catalysed fibrin polymerization. J Biochem 2008;144(03):393-398

99 Yermolenko IS, Lishko VK, Ugarova TP, Magonov SN. High-resolution visualization of fibrinogen molecules and fibrin fibers with atomic force microscopy. Biomacromolecules 2011;12(02): 370-379

100 Joshua V, Schobers L, Titcombe PJ, et al. Antibody responses to de novo identified citrullinated fibrinogen peptides in rheumatoid arthritis and visualization of the corresponding B cells. Arthritis Res Ther 2016;18(01):284

101 Zhao Y, Tian X, Li Z. Prevalence and clinical significance of antibodies to citrullinated fibrinogen (ACF) in Chinese patients with rheumatoid arthritis. Clin Rheumatol 2007;26(09): 1505-1512

102 Cantaert T, Teitsma C, Tak PP, Baeten D. Presence and role of anticitrullinated protein antibodies in experimental arthritis models. Arthritis Rheum 2013;65(04):939-948

103 Shin K, Hong S, Choi E-H, et al. Role of citrullinated fibrinogen peptides in the activation of CD4 T cells from patients with rheumatoid arthritis. Immune Netw 2013;13(04):116-122

104 Šenolt L, Grassi W, Szodoray P. Laboratory biomarkers or imaging in the diagnostics of rheumatoid arthritis? BMC Med 2014;12:49

105 Gianchecchi E, Crinò A, Giorda E, et al. Altered B cell homeostasis and toll-like receptor 9-driven response in type 1 diabetes carriers of the C1858T PTPN22 allelic variant: implications in the disease pathogenesis. PLoS One 2014;9(10):e110755

106 Giltiay NV, Chappell CP, Clark EA. B-cell selection and the development of autoantibodies. Arthritis Res Ther 2012;14 (Suppl 4):S1
107 Menard L, Saadoun D, Isnardi I, et al. The PTPN22 allele encoding an R620W variant interferes with the removal of developing autoreactive B cells in humans. J Clin Invest 2011;121(09): 3635-3644

108 Ho PP, Lee LY, Zhao X, et al. Autoimmunity against fibrinogen mediates inflammatory arthritis in mice. J Immunol 2010;184 (01):379-390

109 Ingegnoli F, Fantini F, Favalli EG, et al. Inflammatory and prothrombotic biomarkers in patients with rheumatoid arthritis: effects of tumor necrosis factor-alpha blockade. J Autoimmun 2008;31(02):175-179

110 Rooney T, Scherzer R, Shigenaga JK, Graf J, Imboden JB, Grunfeld C. Levels of plasma fibrinogen are elevated in well-controlled rheumatoid arthritis. Rheumatology (Oxford) 2011;50(08): $1458-1465$

111 Zhao X, Okeke NL, Sharpe O, et al. Circulating immune complexes contain citrullinated fibrinogen in rheumatoid arthritis. Arthritis Res Ther 2008;10(04):R94

112 Nielen MM, van der Horst AR, van Schaardenburg D, et al. Antibodies to citrullinated human fibrinogen (ACF) have diagnostic and prognostic value in early arthritis. Ann Rheum Dis 2005;64(08):1199-1204

113 Vander Cruyssen B, Cantaert T, Nogueira L, et al. Diagnostic value of anti-human citrullinated fibrinogen ELISA and comparison with four other anti-citrullinated protein assays. Arthritis Res Ther 2006;8(04):R122

114 Hill JA, Bell DA, Brintnell W, et al. Arthritis induced by posttranslationally modified (citrullinated) fibrinogen in DR4-IE transgenic mice. J Exp Med 2008;205(04):967-979

115 van Beers JJBC, Raijmakers R, Alexander L-E, et al. Mapping of citrullinated fibrinogen B-cell epitopes in rheumatoid arthritis by imaging surface plasmon resonance. Arthritis Res Ther 2010; 12(06):R219-R219

116 Nakayama-Hamada M, Suzuki A, Kubota K, et al. Comparison of enzymatic properties between hPADI2 and hPADI4. Biochem Biophys Res Commun 2005;327(01):192-200

117 Sanchez-Pernaute O, Filkova M, Gabucio A, et al. Citrullination enhances the pro-inflammatory response to fibrin in rheumatoid arthritis synovial fibroblasts. Ann Rheum Dis 2013;72(08): 1400-1406

118 Wolberg AS. Thrombin generation and fibrin clot structure. Blood Rev 2007;21(03):131-142

119 Ohba T, Takase Y, Ohhara M, Kasukawa R. Thrombin in the synovial fluid of patients with rheumatoid arthritis mediates proliferation of synovial fibroblast-like cells by induction of platelet derived growth factor. J Rheumatol 1996;23(09):1505-1511

120 Sebbag M, Chapuy-Regaud S, Auger I, et al. Clinical and pathophysiological significance of the autoimmune response to citrullinated proteins in rheumatoid arthritis. Joint Bone Spine 2004;71(06):493-502

121 Yamada R, Suzuki A, Chang X, Yamamoto K. Citrullinated proteins in rheumatoid arthritis. Front Biosci 2005;10:54-64

122 Henschen A, Lottspeich F, Kehl M, Southan C. Covalent structure of fibrinogen. Ann N Y Acad Sci 1983;408:28-43

123 Cohen C, Parry DA. Alpha-helical coiled coils and bundles: how to design an alpha-helical protein. Proteins 1990;7(01):1-15

124 Kollman JM, Pandi L, Sawaya MR, Riley M, Doolittle RF. Crystal structure of human fibrinogen. Biochemistry 2009;48(18): 3877-3886

125 Litvinov RI, Faizullin DA, Zuev YF, Weisel JW. The $\alpha$-helix to $\beta$ sheet transition in stretched and compressed hydrated fibrin clots. Biophys J 2012;103(05):1020-1027

126 Zhmurov A, Kononova O, Litvinov RI, Dima RI, Barsegov V, Weisel JW. Mechanical transition from $\alpha$-helical coiled coils to $\beta$-sheets in fibrin(ogen). J Am Chem Soc 2012;134(50):20396-20402

127 Purohit PK, Litvinov RI, Brown AE, Discher DE, Weisel JW. Protein unfolding accounts for the unusual mechanical behavior of fibrin networks. Acta Biomater 2011;7(06):2374-2383 
128 Greenwald J, Riek R. Biology of amyloid: structure, function, and regulation. Structure 2010;18(10):1244-1260

129 Eisenberg D, Jucker M. The amyloid state of proteins in human diseases. Cell 2012;148(06):1188-1203

130 Pepys MB. Amyloidosis. Annu Rev Med 2006;57:223-241

131 Stangou AJ, Banner NR, Hendry BM, et al. Hereditary fibrinogen A alpha-chain amyloidosis: phenotypic characterization of a systemic disease and the role of liver transplantation. Blood 2010; 115(15):2998-3007

132 Pretorius E, Bester J, Page MJ, Kell DB. The potential of LPSbinding protein to reverse amyloid formation in plasma fibrin of individuals with Alzheimer-type dementia. Front Aging Neurosci 2018;10:257

133 Pretorius E, Page MJ, Engelbrecht L, Ellis GC, Kell DB. Substantial fibrin amyloidogenesis in type 2 diabetes assessed using amyloidselective fluorescent stains. Cardiovasc Diabetol 2017;16(01):141

134 Pretorius E, Page MJ, Mbotwe S, Kell DB. Lipopolysaccharidebinding protein (LBP) can reverse the amyloid state of fibrin seen or induced in Parkinson's disease. PLoS One 2018;13(03): e0192121

135 Pretorius E, Page MJ, Hendricks L, Nkosi NB, Benson SR, Kell DB. Both lipopolysaccharide and lipoteichoic acids potently induce anomalous fibrin amyloid formation: assessment with novel Amytracker ${ }^{\mathrm{TM}}$ stains. J R Soc Interface 2018;15(139):20170941

136 Page MJ, Thomson GJA, Nunes JM, et al. Serum amyloid A binds to fibrin(ogen), promoting fibrin amyloid formation. Sci Rep 2019; 9(01):3102

137 Osaki D, Hiramatsu H. Citrullination and deamidation affect aggregation properties of amyloid $\beta$-proteins. Amyloid 2016; 23(04):234-241

138 Sakono M, Zako T. Amyloid oligomers: formation and toxicity of Abeta oligomers. FEBS J 2010;277(06):1348-1358

139 Connolly M, Marrelli A, Blades M, et al. Acute serum amyloid A induces migration, angiogenesis, and inflammation in synovial cells in vitro and in a human rheumatoid arthritis/SCID mouse chimera model. J Immunol 2010;184(11):6427-6437

140 Cunnane G, Grehan S, Geoghegan S, et al. Serum amyloid A in the assessment of early inflammatory arthritis. J Rheumatol 2000;27 (01):58-63

141 Hwang YG, Balasubramani GK, Metes ID, Levesque MC, Bridges SL Jr, Moreland LW. Differential response of serum amyloid A to different therapies in early rheumatoid arthritis and its potential value as a disease activity biomarker. Arthritis Res Ther 2016;18 (01):108

142 Targońska-Stępniak B, Majdan M. Serum amyloid A as a marker of persistent inflammation and an indicator of cardiovascular and renal involvement in patients with rheumatoid arthritis. Mediators Inflamm 2014;2014:793628

143 Cunnane G, Whitehead AS. Amyloid precursors and amyloidosis in rheumatoid arthritis. Best Pract Res Clin Rheumatol 1999;13 (04):615-628

144 Husby G, Husebekk A, Skogen B, et al. Serum amyloid A (SAA)the precursor of protein $A A$ in secondary amyloidosis. Adv Exp Med Biol 1988;243:185-192

145 Steel DM, Whitehead AS. The major acute phase reactants: Creactive protein, serum amyloid $P$ component and serum amyloid A protein. Immunol Today 1994;15(02):81-88

146 O'Hara R, Murphy EP, Whitehead AS, FitzGerald O, Bresnihan B. Acute-phase serum amyloid A production by rheumatoid arthritis synovial tissue. Arthritis Res 2000;2(02):142-144

147 Kumon Y, Suehiro T, Hashimoto K, Nakatani K, Sipe JD. Local expression of acute phase serum amyloid A mRNA in rheumatoid arthritis synovial tissue and cells. J Rheumatol 1999;26(04):785-790

148 Urieli-Shoval S, Meek RL, Hanson RH, Eriksen N, Benditt EP. Human serum amyloid A genes are expressed in monocyte/ macrophage cell lines. Am J Pathol 1994;145(03):650-660

149 Mullan RH, Bresnihan B, Golden-Mason L, et al. Acute-phase serum amyloid A stimulation of angiogenesis, leukocyte recruit- ment, and matrix degradation in rheumatoid arthritis through an NF-kappaB-dependent signal transduction pathway. Arthritis Rheum 2006;54(01):105-114

150 Kell DB, Pretorius E. Proteins behaving badly. Substoichiometric molecular control and amplification of the initiation and nature of amyloid fibril formation: lessons from and for blood clotting. Prog Biophys Mol Biol 2017;123:16-41

151 Naito M.Porphyromonas gingivalis-induced platelet aggregation in human plasma. Journal of Oral Biosciences. 2007;49(03):173-179

152 Stobernack T, du Teil Espina M, Mulder LM, et al. A secreted bacterial peptidylarginine deiminase can neutralize human innate immune defenses. MBio 2018;9(05):e01704-e01718

153 Abdullah S-N, Farmer E-A, Spargo L, Logan R, Gully N. Porphyromonas gingivalis peptidylarginine deiminase substrate specificity. Anaerobe 2013;23:102-108

154 Wegner N, Wait R, Sroka A, et al. Peptidylarginine deiminase from Porphyromonas gingivalis citrullinates human fibrinogen and $\alpha$-enolase: implications for autoimmunity in rheumatoid arthritis. Arthritis Rheum 2010;62(09):2662-2672

155 Potempa J, Pike R, Travis J. The multiple forms of trypsin-like activity present in various strains of Porphyromonas gingivalis are due to the presence of either Arg-gingipain or Lys-gingipain. Infect Immun 1995;63(04):1176-1182

156 McGraw WT, Potempa J, Farley D, Travis J. Purification, characterization, and sequence analysis of a potential virulence factor from Porphyromonas gingivalis, peptidylarginine deiminase. Infect Immun 1999;67(07):3248-3256

157 Quirke A-M, Lugli EB, Wegner N, et al. Heightened immune response to autocitrullinated Porphyromonas gingivalis peptidylarginine deiminase: a potential mechanism for breaching immunologic tolerance in rheumatoid arthritis. Ann Rheum Dis 2014;73(01):263-269

158 Montgomery AB, Kopec J, Shrestha L, et al. Crystal structure of Porphyromonas gingivalis peptidylarginine deiminase: implications for autoimmunity in rheumatoid arthritis. Ann Rheum Dis 2016;75(06):1255-1261

159 Yamakawa M, Ouhara K, Kajiya M, et al. Porphyromonas gingivalis infection exacerbates the onset of rheumatoid arthritis in SKG mice. Clin Exp Immunol 2016;186(02):177-189

160 Khandpur R, Carmona-Rivera C, Vivekanandan-Giri A, et al. NETs are a source of citrullinated autoantigens and stimulate inflammatory responses in rheumatoid arthritis. Sci Transl Med 2013;5 (178):178ra40

161 Bartold PM, Marino V, Cantley M, Haynes DR. Effect of Porphyromonas gingivalis-induced inflammation on the development of rheumatoid arthritis. J Clin Periodontol 2010;37(05):405-411

162 Lönn J, Ljunggren S, Klarström-Engström K, Demirel I, Bengtsson $\mathrm{T}$, Karlsson H. Lipoprotein modifications by gingipains of Porphyromonas gingivalis. J Periodontal Res 2018;53(03):403-413

163 Bale BF, Doneen AL, Vigerust DJ. High-risk periodontal pathogens contribute to the pathogenesis of atherosclerosis. Postgrad Med J 2017;93(1098):215-220

164 Imamura T, Tanase S, HamamotoT, Potempa J, Travis J. Activation of blood coagulation factor IX by gingipains R, arginine-specific cysteine proteinases from Porphyromonas gingivalis. Biochem J 2001;353(Pt 2):325-331

165 Imamura T, Potempa J, Tanase S, Travis J. Activation of blood coagulation factor $\mathrm{X}$ by arginine-specific cysteine proteinases (gingipain-Rs) from Porphyromonas gingivalis. J Biol Chem 1997; 272(25):16062-16067

166 Imamura T, Banbula A, Pereira PJ, Travis J, Potempa J. Activation of human prothrombin by arginine-specific cysteine proteinases (Gingipains R) from Porphyromonas gingivalis. J Biol Chem 2001; 276(22):18984-18991

167 Guo Y, Nguyen KA, Potempa J. Dichotomy of gingipains action as virulence factors: from cleaving substrates with the precision of a surgeon's knife to a meat chopper-like brutal degradation of proteins. Periodontol 2000 2010;54(01):15-44 
168 Imamura T, Potempa J, Pike RN, Moore JN, Barton MH, Travis J. Effect of free and vesicle-bound cysteine proteinases of Porphyromonas gingivalis on plasma clot formation: implications for bleeding tendency at periodontitis sites. Infect Immun 1995;63 (12):4877-4882

169 Lourbakos A, Yuan YP, Jenkins AL, et al. Activation of proteaseactivated receptors by gingipains from Porphyromonas gingivalis leads to platelet aggregation: a new trait in microbial pathogenicity. Blood 2001;97(12):3790-3797

170 Adams B, Nunes JM, Page MJ, et al. Parkinson's disease: a systemic inflammatory disease accompanied by bacterial inflammagens. Front Aging Neurosci 2019;11(210):210

171 McInnes IB, Schett G. The pathogenesis of rheumatoid arthritis. N Engl J Med 2011;365(23):2205-2219

172 Vossenaar ER, Smeets TJ, Kraan MC, Raats JM, van Venrooij WJ, Tak PP. The presence of citrullinated proteins is not specific for rheumatoid synovial tissue. Arthritis Rheum 2004;50(11): 3485-3494

173 van der Helm-van Mil AH, Verpoort KN, Breedveld FC, Huizinga TW, Toes RE, de Vries RR. The HLA-DRB1 shared epitope alleles are primarily a risk factor for anti-cyclic citrullinated peptide antibodies and are not an independent risk factor for development of rheumatoid arthritis. Arthritis Rheum 2006;54(04):1117-1121

174 Vossenaar ER, Radstake TR, van der Heijden A, et al. Expression and activity of citrullinating peptidylarginine deiminase enzymes in monocytes and macrophages. Ann Rheum Dis 2004;63(04):373-381

175 Chang X, Yamada R, Suzuki A, et al. Localization of peptidylarginine deiminase 4 (PADI4) and citrullinated protein in synovial tissue of rheumatoid arthritis. Rheumatology (Oxford) 2005;44 (01):40-50

176 Smiley ST, King JA, Hancock WW. Fibrinogen stimulates macrophage chemokine secretion through toll-like receptor 4. J Immunol 2001;167(05):2887-2894

177 Hsieh JY, Smith TD, Meli VS, Tran TN, Botvinick EL, Liu WF. Differential regulation of macrophage inflammatory activation by fibrin and fibrinogen. Acta Biomater 2017;47:14-24

178 Rubel C, Fernández GC, Dran G, Bompadre MB, Isturiz MA, Palermo MS. Fibrinogen promotes neutrophil activation and delays apoptosis. J Immunol 2001;166(03):2002-2010

179 Guo M, Sahni SK, Sahni A, Francis CW. Fibrinogen regulates the expression of inflammatory chemokines through NF-kappaB activation of endothelial cells. Thromb Haemost 2004;92(04): 858-866

180 Liu X, Piela-Smith TH. Fibrin(ogen)-induced expression of ICAM1 and chemokines in human synovial fibroblasts. J Immunol 2000;165(09):5255-5261

181 Weinberg JB, Pippen AM, Greenberg CS. Extravascular fibrin formation and dissolution in synovial tissue of patients with osteoarthritis and rheumatoid arthritis. Arthritis Rheum 1991; 34(08):996-1005

182 Clavel C, Ceccato L, Anquetil F, Serre G, Sebbag M. Among human macrophages polarised to different phenotypes, the M-CSForiented cells present the highest pro-inflammatory response to the rheumatoid arthritis-specific immune complexes containing ACPA. Ann Rheum Dis 2016;75(12):2184-2191

183 Sokolove J, Zhao X, Chandra PE, Robinson WH. Immune complexes containing citrullinated fibrinogen costimulate macrophages via Toll-like receptor 4 and Fcr receptor. Arthritis Rheum 2011;63(01):53-62

184 Zhu W, Li X, Fang S, et al. Anti-citrullinated protein antibodies induce macrophage subset disequilibrium in RA patients. Inflammation 2015;38(06):2067-2075

185 Bianchi ME. DAMPs, PAMPs and alarmins: all we need to know about danger. J Leukoc Biol 2007;81(01):1-5

186 Hu F, Li Y, Zheng L, et al. Toll-like receptors expressed by synovial fibroblasts perpetuate Th1 and th17 cell responses in rheumatoid arthritis. PLoS One 2014;9(06):e100266
187 Bartok B, Firestein GS. Fibroblast-like synoviocytes: key effector cells in rheumatoid arthritis. Immunol Rev 2010;233(01): 233-255

188 Makarov SS. NF-kappa B in rheumatoid arthritis: a pivotal regulator of inflammation, hyperplasia, and tissue destruction. Arthritis Res 2001;3(04):200-206

189 Smolen JS, Redlich K, Zwerina J, Aletaha D, Steiner G, Schett G. Pro-inflammatory cytokines in rheumatoid arthritis: pathogenetic and therapeutic aspects. Clin Rev Allergy Immunol 2005;28 (03):239-248

190 Siebert S, Tsoukas A, Robertson J, McInnes I. Cytokines as therapeutic targets in rheumatoid arthritis and other inflammatory diseases. Pharmacol Rev 2015;67(02):280-309

191 Bystrom J, Clanchy FI, Taher TE, et al. TNF $\alpha$ in the regulation of Treg and Th17 cells in rheumatoid arthritis and other autoimmune inflammatory diseases. Cytokine 2018;101:4-13

192 Rho YH, Chung CP, Oeser A, et al. Inflammatory mediators and premature coronary atherosclerosis in rheumatoid arthritis. Arthritis Rheum 2009;61(11):1580-1585

193 Kawashima M, Miossec P. Effect of treatment of rheumatoid arthritis with infliximab on IFN gamma, IL4, T-bet, and GATA-3 expression: link with improvement of systemic inflammation and disease activity. Ann Rheum Dis 2005;64(03):415-418

194 Pawlik A, Ostanek L, Brzosko I, et al. Therapy with infliximab decreases the CD4+CD28-T cell compartment in peripheral blood in patients with rheumatoid arthritis. Rheumatol Int 2004;24(06):351-354

195 Abbas S, Zhang YH, Clohisy JC, Abu-Amer Y. Tumor necrosis factor-alpha inhibits pre-osteoblast differentiation through its type-1 receptor. Cytokine 2003;22(1-2):33-41

196 Lam J, Takeshita S, Barker JE, Kanagawa O, Ross FP, Teitelbaum SL. TNF-alpha induces osteoclastogenesis by direct stimulation of macrophages exposed to permissive levels of RANK ligand. J Clin Invest 2000;106(12):1481-1488

197 Pignatelli P, De Biase L, Lenti L, et al. Tumor necrosis factor-alpha as trigger of platelet activation in patients with heart failure. Blood 2005;106(06):1992-1994

198 Chen W, Wang Q Ke Y, Lin J. Neutrophil function in an inflammatory milieu of rheumatoid arthritis. J Immunol Res 2018; 2018:8549329

199 Khawaja AA, Pericleous C, Ripoll VM, Porter JC, Giles IP. Autoimmune rheumatic disease IgG has differential effects upon neutrophil integrin activation that is modulated by the endothelium. Sci Rep 2019;9(01):1283

200 Thieblemont N, Wright HL, Edwards SW, Witko-Sarsat V. Human neutrophils in auto-immunity. Paper presented at: Seminars in Immunology; 2016

201 Brinkmann V, Reichard U, Goosmann C, et al. Neutrophil extracellular traps kill bacteria. Science 2004;303(5663):1532-1535

202 Zou Y, Chen X, Xiao J, et al. Neutrophil extracellular traps promote lipopolysaccharide-induced airway inflammation and mucus hypersecretion in mice. Oncotarget 2018;9(17): 13276-13286

203 Clark SR, Ma AC, Tavener SA, et al. Platelet TLR4 activates neutrophil extracellular traps to ensnare bacteria in septic blood. Nat Med 2007;13(04):463-469

204 Keshari RS, Jyoti A, Dubey M, et al. Cytokines induced neutrophil extracellular traps formation: implication for the inflammatory disease condition. PLoS One 2012;7(10):e48111

205 Spengler J, Lugonja B, Ytterberg AJ, et al. Release of active peptidyl arginine deiminases by neutrophils can explain production of extracellular citrullinated autoantigens in rheumatoid arthritis synovial fluid. Arthritis Rheumatol 2015;67(12):3135-3145

206 Varjú I, Kolev K. Networks that stop the flow: a fresh look at fibrin and neutrophil extracellular traps. Thromb Res 2019;182:1-11

207 Fuchs TA, Brill A, Duerschmied D, et al. Extracellular DNA traps promote thrombosis. Proc Natl Acad Sci U S A 2010;107(36): 15880-15885 
208 Varjú I, Longstaff C, Szabó L, et al. DNA, histones and neutrophil extracellular traps exert anti-fibrinolytic effects in a plasma environment. Thromb Haemost 2015;113(06):1289-1298

209 Chang X, Yamada R, Sawada T, Suzuki A, Kochi Y, Yamamoto K. The inhibition of antithrombin by peptidylarginine deiminase 4 may contribute to pathogenesis of rheumatoid arthritis. Rheumatology (Oxford) 2005;44(03):293-298
210 Longstaff C, Varjú I, Sótonyi P, et al. Mechanical stability and fibrinolytic resistance of clots containing fibrin, DNA, and histones. J Biol Chem 2013;288(10):6946-6956

211 Xaus J, Comalada M, Valledor AF, et al. LPS induces apoptosis in macrophages mostly through the autocrine production of TNFalpha. Blood 2000;95(12):3823-3831 